University of Michigan Law School

University of Michigan Law School Scholarship Repository

Law \& Economics Working Papers

3-1-2013

\title{
Methods for Multicountry Studies of Corporate Governance (and Evidence from the BRIKT Countries)
}

\author{
Bernard S. Black \\ Northwestern University, bblack@northwestern.edu \\ Antonio Gledson De Carvalho \\ Fundacao Getulio Vargas School of Business at Sao Paulo, gldeson.carvalho@fgv.br \\ Vikramaditya Khanna \\ University of Michigan Law School, vskhanna@umich.edu \\ Woochan Kim \\ Korea University Business School, wckim@korea.ac.kr \\ B. Burcin Yurtoglu \\ WHU - Otto Beisheim School of Management, BURCIN.YURTOGLU@UNIVIE.AC.AT
}

Follow this and additional works at: https://repository.law.umich.edu/law_econ_current

Part of the Business Organizations Law Commons, and the Law and Economics Commons

\section{Working Paper Citation}

Black, Bernard S.; De Carvalho, Antonio Gledson; Khanna, Vikramaditya; Kim, Woochan; and Yurtoglu, B. Burcin, "Methods for Multicountry Studies of Corporate Governance (and Evidence from the BRIKT Countries)" (2013). Law \& Economics Working Papers. 74.

https://repository.law.umich.edu/law_econ_current/74

This Article is brought to you for free and open access by University of Michigan Law School Scholarship Repository. It has been accepted for inclusion in Law \& Economics Working Papers by an authorized administrator of University of Michigan Law School Scholarship Repository. For more information, please contact mlaw.repository@umich.edu. 


\title{
Methods for Multicountry Studies of Corporate Governance (and Evidence from the BRIKT Countries)
}

(draft March 2013)

\author{
Bernard Black \\ Northwestern University, Law School and Kellogg School of Management \\ Antonio Gledson de Carvalho \\ Fundacao Getulio Vargas School of Business at Sao Paulo \\ Vikramaditya Khanna \\ University of Michigan Law School \\ Woochan Kim \\ Korea University Business School \\ Burcin Yurtoglu \\ WHU - Otto Beisheim School of Management
}

European Corporate Governance Institute

Finance Working Paper No. xxx/2013

Northwestern University School of Law

Law and Economics Research Paper No. 13-05

This paper can be downloaded without charge from the Social Science Research Network electronic library at: http://ssrn.com/abstract $=2219525$ 
Law \& Economics W orking Papers, Art. 74 [2013]

\title{
Methods for Multicountry Studies of Corporate Governance (and Evidence from the BRIKT Countries)*
}

\author{
(C) 2013 Bernard S. Black. All rights reserved.
}

\begin{abstract}
We discuss the perils in multicountry studies of corporate governance (CG), focusing on emerging markets. The existing studies are massively multicountry studies, which cover many firms across many countries, but rely on the same limited governance elements in each countries, have few firm-level control variables, and use pure-cross-sectional data. This paper discusses the severe data and construct validity issues in these studies, proposes methods to respond to those issues, and applies those methods through a study of five major emerging markets (Brazil, India, Korea, Russia, and Turkey). We develop unique time-series datasets on governance in each country. We address construct validity by building country-specific indices which reflect local norms and institutions. These similar-but-not-identical indices predict higher firm market value, both in each country and when pooled across countries. In contrast, a "common index" that uses the same elements in each country, has no predictive power. Firm fixed effects results differ substantially from cross-sectional or pooled OLS, and firm random effects. Results are also sensitive to choice of control variables (strongly so with the weaker cross-sectional and pooled OLS specifications), and to the functional form for the dependent variable and how one addresses outliers.
\end{abstract}

Keywords: Brazil, Korea, India, Russia, Turkey, corporate governance, boards of directors, disclosure, shareholder rights.

JEL codes: G18, G30, G34, G39, K22, K29

* We thank conference and workshop participants at Ackerman Conference on Corporate Governance at Bar Ilan University (2012), National University of Singapore, Centre for Governance, Institutions \& Organizations Academic Conference (2012) (keynote speech); Conference on The Role of Intermediaries in Corporate Governance (Notre Dame Law School (2012), and NYU Law School (2013) for comments and suggestions, and Humberto Gallucci, Pranav Garg, Lorena Keller, Terence Leong, and Joelson Sampaio for research assistance. We thank Northwestern and Michigan Law Schools for financial support for our India surveys, Corporate Governance Forum of Turkey, at the Sabanci University (Istanbul) and WHU - Otto Beisheim School of Management for financial support for data collection in Turkey. We are grateful to the many company executives in Brazil and India who took the time to respond to our surveys, to the Bovespa stockmarket, the Brazilian Comissao de Valores Mobiliarios, the Instituto Brasileiro de Governança Corporativa, and (Indian) National Stock Exchange and Bombay Stock Exchange, and the Indian Institute of Management, Bangalore for supporting our survey efforts, and the Korea Corporate Governance Service for providing their survey results to us. 


\section{1 - Introduction}

We study here the empirical challenges in multicountry studies of the effect of firm-level corporate governance on firm market value, focusing on emerging markets, and propose methods to respond to those challenges. ${ }^{1}$ For many topics in corporate finance, the US, UK, and a few other developed countries provide an adequate "laboratory": a large sample of public companies, good financial disclosure, and time series data. For corporate governance, however, one cannot infer cross-country regularities by studying one or two countries, nor understand governance in emerging markets by studying developed ones. ${ }^{2}$ The aspects of corporate governance that are likely to affect firm value also depend on prevailing legal rules and other institutions, which vary widely across countries.

When studying corporate governance in emerging markets, especially across markets, we need to confront an array of problems. A central issue is "construct validity" - a term we borrow from education and psychology (see Shadish, Cook and Campbell, 2002, for an overview). A governance index is a construct that imperfectly measures unobserved underlying governance. There is no direct way to quantify the gap between the construct and the underlying concept. Moreover, what matters in governance often depends on local norms and institutions; thus, the same construct may fit underlying governance well in some countries but poorly in others.

A second core problem is lack of data on governance, especially lack of consistent, time series data across countries. Lack of data on governance also reinforces concerns with construct validity. As we will show, it is impossible to use public data to build a broad governance index based on common elements, even across the five countries we study. It is nearly impossible to do so even relying on private surveys of firms (as we do in Brazil, India, and Korea). If we try, the best index we can build predicts almost nothing.

A third problem is endogeneity. Natural experiments can sometimes be found in individual countries, but address limited aspects of governance. The next best approach, and the one we pursue here, is to build panel data and use firm fixed (or at least random) effects, plus extensive control variables, to limit one central endogeneity concern, omitted variable bias (OVB). Yet, both time-series data on

${ }^{1}$ We put aside the effects of country-level governance - the "LLSV and all that" line of research on how country level governance affects capital markets and economic performance. See, e.g., La Porta et al. (1997, 1998a, 1998b); Glaeser, Johnson and Shleifer (2001); Levine and Zervos (1998).

2 In the US and UK, a dominant concern is whether the firm is well managed. Many firms are widely held, so takeover defenses are central in measuring governance (e.g., Gompers, Ishii and Metrick, 2003; Bebchuk, Cohen, and Ferrell, 2009). In emerging markets, most firms have a control group, making takeover defenses irrelevant. A major concern is limiting self-dealing by controllers (e.g., Bebchuk and Hamdani, 2009; Bertrand, Duflo, and Mullainathan, 2004). 
governance and rich data on control variables are hard to come by. Narrow measures of governance that focus on, say, board independence or disclosure, face additional problems. Different aspects of governance often correlate. The omitted aspects of governance are a source of OVB for the included aspects. Narrower measures also exacerbate construct validity concerns. Finally, in many countries, the number of firms with governance data is limited. Sometimes, financial databases are imperfect.

Yet, most what we think we know about the relation between corporate governance and market value in emerging markets comes from studies with most or all of these problems. The literature contains two principal strategies: single country studies ("deep and narrow”) and studies that pool firms across many countries ("massively multicountry"). Deep and narrow studies can overcome some of these problems, but suffer from limited sample sizes and lack of generalizability. Massively multicountry studies can provide reasonable sample sizes and potentially offer generalizability, but to date, have failed to address the remaining obstacles. ${ }^{3}$

In this article we describe the perils in multicountry studies of corporate governance, and seek to make progress on all three core dimensions: construct validity, data on governance and control variables, and endogeneity. We construct, largely by hand, unique time-series datasets on governance in each of five important emerging markets - Brazil, Russia, India, Korea, and Turkey ("BRIKT" countries). ${ }^{4}$ Together, these countries provide a representative sample of the results one might expect in moderately developed emerging markets. They differ in many ways, including legal traditions, language, culture, geographic location, and background legal rules. Our governance dataset covers many but far from all public firms in each country. It is, we believe, close to the best that one can realistically build across multiple emerging markets. ${ }^{5}$ We use this rich dataset, plus extensive control variables: (1) to explore how each of the above methods weaknesses affects results; and (2) offer a more robust approach to understanding how corporate governance affects firm value in emerging markets.

We address construct validity by building country-specific indices which reflect local norms and institutions. Each is comprised (data permitting) of subindices for board structure, board procedure, disclosure, ownership structure, minority shareholder rights, and control of related party transactions. Each subindex is comprised of one or more "elements" that seek to capture specific aspects of governance

3 Studies using this approach include Durnev and Kim (2005); Klapper and Love (2004); Dahya, Dimitrov, and McConnell (2008) (board independence); Doidge, Karolyi and Stulz (2007). Developed market studies using this approach include Aggarwal et al. (2009).

${ }^{4}$ This is a play on the World Bank's use of BRIC (Brazil, Russia, India, China) as key emerging markets. See http://en.wikipedia.org/wiki/BRIC. Some would add Turkey. We do not study China because the heavy dominance of state-controlled firms in China means that generalizability is suspect, and study Korea instead.

${ }^{5}$ At least short of a World Bank scale multicountry project, with substantial funding for data collection. 
that we consider relevant in each country. The indices and subindices for each country are broadly similar, and seek to capture similar underlying governance concepts. But the individual elements reflect the norms, institutions, and data limitations in each country.

As an example of the problems with using only common elements across countries, consider an audit committee. These committees are often thought to be a useful component of board structure. They might in fact be valuable - but we can't measure their value in India and Turkey, where they are required, nor in Russia, where board committees are formally not permitted. And we can learn little in Brazil, where many firms employ the substitute Brazilian institution of the "fiscal board. Our approach, in contrast, involves building a Brazil board structure subindex that takes both institutions into account.

Having built country-specific indices, we then assess whether governance affects firm market value (proxied by Tobin's $q$ ) in each country and find substantial differences across firm fixed effects (FE), random effects (RE), cross-sectional OLS, or pooled OLS results. We conduct extensive sensitivity tests and find that the coefficients on the country indices are somewhat sensitive to control variables (strongly so with the weaker cross-sectional and pooled OLS specifications), and quite sensitive to the functional form we choose for the dependent variable and how we address outliers.

The new methodology we employ - conducting a multicountry study using similar-but-notidentical country-level governance indices - can be seen as a "middle way" between single-country studies, from which it is hard to generalize; and "massively multicountry" studies. We develop methods appropriate for (cautiously) generalizing across a number of countries, which may provide a way to develop a more credible connection between governance and firm value or performance. ${ }^{6}$

Some lessons from this project for efforts to assess whether a change in firm governance will cause a change in firm value. Most centrally, we build country-specific indices which capture, as best we can, the unobserved underlying concepts of sound governance. A "generic" index that uses common elements across countries is unlikely to capture much of interest. Researchers also need to: (i) move toward panel data with firm fixed (or at least random) effects; (ii) develop broad governance indices; (iii) vary how one specifies the dependent variable and handles outliers; and (iv) use extensive control variables. Not every paper will achieve all of these steps, but one should place little weight on papers which have none or few of them.

\footnotetext{
6 This research complements our studies of individual countries. At the risk of an annoying amount of self-citation: In Brazil, see Black, de Carvalho and Gorga (2010, 2012); Black, de Carvalho and Sampaio (2012), de Carvalho and Pennacchi (2012). In India, see Balasubramanian, Black and Khanna (2010) Black and Khanna (2007); Dharmapala and Khanna (2013). In Korea, see Black, Jang and Kim (2006a); Black and Kim (2012); Black, Kim, Jang and Park (2013). In Russia, see Black (2001), Black, Love and Rachinsky (2006). In Turkey, see Ararat, Orbay, and Yurtoglu (2010); Ararat, Black and Yurtoglu (2013).
} 
This paper proceeds as follows. Section 2 describes our country-level governance indices. Section 3 develops our methodology. Section 4 presents results for individual countries. Section 5 presents pooled cross-country results. Section 6 concludes. We skip the usual literature review, and refer readers to the recent review by one of us (Claessens and Yurtoglu, 2013), and the briefer review in Black, de Carvalho and Gorga (2012). We focus on methods and on results for an overall governance index. In a companion article, we study which subindices and elements predict firm market value, for which firms, in which countries (Black et al., 2013). Disclosure is consistently valuable across countries, board structure has predictive power in some countries, but little else about governance has a consistent effect.

\section{Samples, Governance Surveys, and Indices}

To build governance indices, we rely on private surveys in Brazil (2004, 2006, 2009); India (2006, 2007, 2012), Korea (1998-2004), public data plus extensive hand collection in Turkey (20062011), and a mix of public and private data in Russia (1999-2005). ${ }^{7}$

\subsection{Brazil as Illustrative Example: Governance Survey}

We use Brazil here to illustrate our approach. An expanded working paper version of this article provides similar information for other countries (Black et al., 2013b). Our Brazil index is based on extensive survey distributed in 2005, 2007, and 2009 to all public firms (for details, see Black, de Carvalho and Gorga, 2010). The survey is similar, where feasible, to the India and Korea surveys. Table 1 summarizes the replies. We obtain sufficient information from at least one survey to build our Brazil Corporate Governance Index (BCGI) and compute Tobin's $q$ and control variables for 142 of 254 sampleeligible firms (56\%). The respondents represent $72 \%$ of the market cap of eligible firms; thus, respondents tend to be larger firms. However, only 72 firms answered two or more surveys. ${ }^{8}$ We also obtain information from the CVM website, firm charters, and firm annual reports. ${ }^{9}$

\footnotetext{
7 We exclude state-controlled firms, subsidiaries of foreign companies, and banks. The Brazil, India, and Korea surveys are available on request. Russia differs from the other countries. We rely on six different privately created governance indices, rather than building our own index (see Black, Love, and Rachinsky, 2006, for details). Russia also has weaker data for control variables. Statements in this paper about regularities across countries include Russia only to the extent that the underlying data is available. Our challenges with Russia underscore the general theme of this paper about the challenges in obtaining data on governance across countries.

${ }^{8}$ India and Russia pose similar concerns with sample selection bias and a highly unbalanced panel. We have close to complete coverage of public firms in Korea and Turkey. See expanded working paper for details.
}

9 We also obtain data on firms' market capitalization and listing level from Bovespa, at www.bovespa.com.br/principal.asp; financial data from the Economatica database, at www.economatica.com; basic company information from annual reports, available from InfoInvest at www.infoinvest.com.br; and information on cross-listing from databases maintained by Bank of New York, at www.adrbny.com, Citibank, at 


\subsection{Brazil Corporate Governance Index and Subindices}

Table 2 lists the subindices and their elements for Brazil, India, Korea, and Turkey. Table 2 also indicates which elements are non-public (available only from our surveys). For each element, it indicates in which countries the element is used, "available" but not used (we have data, or could obtain it without great difficulty) or "feasible" (we could compute it with substantial additional effort, usually to handcollect data from company annual reports). We include an element in the overall index only if we judge it to be "useful" if: (i) it is often believed to correspond to good governance (sometimes with empirical support, but more often not); (ii) we have reasonably complete data; (iii) there is reasonable variation across firms (thus, the index does not include elements required by law); and (iv) the element is sufficiently different from another element to justify inclusion. BCGI is composed of six subindices, which in turn reflect 41 useful firm attributes. Most elements are dichotomous (coded as "1" if a firm has the attribute and "0" otherwise). We normalize continuous variables to run from $0 \sim 1$.

Brazil Board Structure Subindex (7 elements). Board independence is seen as a core element of corporate governance (e.g., OECD, 2004; Dahya, Dimitrov and McConnell, 2008). An audit committee, can help to ensure the integrity of financial reporting (e.g., Klein, 2002). In Brazil, the fiscal board plays a role in oversight of financial reporting similar to an audit committee, and often substitutes for the audit committee, so our governance index considers this institution as well. ${ }^{10}$

Brazil Board Procedure Subindex (6 elements). Board and internal firm procedures are common components of governance indices. Their effect on firm value remains an open question. Our index assesses whether a board meets at least four times per year, whether it regularly evaluates the CEO and other executives, whether board members receive materials in advance of board meetings, and whether the firm has a bylaw governing the board and a code of ethics.

Brazil Disclosure Subindex (11 elements). Disclosure is associated with higher firm market value (e.g., Durnev and Kim, 2005). We identify 11 usable disclosure elements, which include, among other things, whether the firm prepares financial statements that meet international accounting standards; prepares English language financial statements; provides financial disclosures, such as a statement of cash

wwss.citissb.com/adr/www/brokers/index.htm, CVM, at www.cvm.gov.br, Deutsche Bank, at www.adr.db.com, and JP Morgan, at www.adr.com.

10 The fiscal board is elected by shareholders and must include a representative chosen by minority shareholders. The members of the fiscal board report individually at the annual shareholder meeting on whether they approve the company's financial statements. For Brazilian companies that cross-list in the U.S., which are required to have an audit committee under the Sarbanes-Oxley law, the U.S. Securities and Exchange Commission treats the fiscal board as an acceptable substitute. 
flows, that are common in other countries but not required in Brazil; posts financial statements on a company web site; discloses its major shareholders; and discloses related party transactions (RPTs). ${ }^{11}$

Brazil Ownership Subindex (5 elements). A "wedge" between cash flow rights and voting rights can provide incentives for self-dealing (Claessens, Djankov, Fan, and Lang, 2002). Many Brazilian firms use dual-class structures, with insiders holding most of the voting common shares and outsiders holding non-voting, common-equivalent preferred shares. The ownership subindex includes the fraction of nonvoting shares; the largest shareholder's fractional ownership of voting shares; the wedge between this person's voting and economic rights; whether the control group is small (and hence more cohesive); and whether there are large outside blockholders who can monitor the controller.

Brazil RPT Subindex (5 elements): RPTs are a core concern in many emerging markets (e.g., Bae, Kang and Kim, 2002; Atanasov et al., 2010). Our RPT subindex includes four elements relating to the existence of RPTs and approval procedures for these transactions.

Brazil Shareholder Rights Subindex (7 elements): Minority shareholders rights are often seen as an important aspect of governance (e.g., Atanasov et al., 2010; Bennedsen, Nielsen, and Nielsen, 2012). We extract from the survey seven elements related to these rights including: takeout rights on a sale of control; freezeout rights (above the legal minimum); shareholder rights for election of directors; arbitration of disputes with shareholders; preemptive rights; and $25 \%$ minimum free float.

Computing and Combining Subindices. Within each subindex, we weight each element equally. Thus, to compute Brazil Disclosure Subindex, we sum the 12 elements. If an element value is missing, we use the average score for the nonmissing values. ${ }^{12}$ We reweight so each subindex runs from $0 \sim 100$. BCGI score is an average of the subindex scores. BCGI values range from 19.1 to 91.5 (mean $=62.1$. For regressions, we normalize each subindex to mean $0, \sigma=1$, sum the normalized subindices, and normalize the sum; BCGI is thus a renormalized sum of normalized subindices.

\subsection{Other Country Governance Indices}

India. In India, similar to Brazil, we rely on our own surveys, conducted in 2006, 2007, and 2012, for governance data. India has stronger rules than Brazil; thus some Brazil governance elements are not meaningful in India; conversely many India elements are not available or not meaningful in Brazil. We build an India Corporate Governance Index (ICGI), comprised of 42 elements, with

\footnotetext{
11 For this and some other elements, it is unclear which subindex to best assign them to. For example, is disclosure of RPTs best assigned to Disclosure Subindex or to RPT Subindex? We use our own (debatable) judgment.

12 Brazil RPT Subindex is an exception. If the firm's charter forbids RPTs, the firm receives a score of 5. If RPTs are not forbidden but firm does not engage in them, it receives a score of 4 . If a firm engages in RPTs, it scores $0 \sim 3$ depending on the procedure for approving RPTs.
} 
subindices for Board Structure (6 elements); Board Procedure (13 elements); Disclosure (13 elements); RPTs (6 elements); and Shareholder Rights (4 elements). We cannot construct a meaningful ownership subindex because India has a one share, one vote rule, and few pyramids. We use similar elements in Brazil and India to the extent feasible. Nonetheless, the two indices have only 14 common elements. ICGI values range from 24.6 to 86.9 (mean $=59.2 .^{13}$

Korea. We have Korean governance data from 1998-2004. For 2001-2004, we rely on a survey of all Korea Stock Exchange firms by the Korea Corporate Governance Service (KCGS). We hand collect data to extend the index back to 1998 (see Black and Kim, 2012, for details). We build a Korea Corporate Governance Index (KCGI), comprised of 27 elements, with subindices for Board Structure (7 elements); Board Procedure (12 elements); Disclosure (3 elements); Ownership (1 element); and Shareholder Rights (4 elements). We lack the data to construct an RPT Subindex. ${ }^{14}$ KCGI values range from 7.9 to $88.3($ mean $=33.9)$.

Turkey. We have Turkish governance data from 2006-2011. We hand-collect data from firm corporate governance reports, annual reports, charters, financial statement footnotes, and firm websites. Our Turkey Corporate Governance Index (TCGI) includes 49 elements, divided into subindices for Board Structure (8 elements); Board Procedure (5 elements); Disclosure (23 elements); Ownership (5 elements); and Shareholder Rights (8 elements). We lack enough data to construct an RPT Subindex. ${ }^{15}$ TCGI values range from 9.3 to $74.5($ mean $=42.4)$.

In India, Korea, and Turkey, we construct subindices and an overall country index in the same manner as for Brazil.

Russia. In Russia, we rely not on a single index but instead on six separate indices, created by others, covering different firms at different times over 1999-2005. Because we do not control how the indices are built, we cannot build subindices. We normalize each index and use the normalized indices to build an overall Russia Corporate Governance Index (RCGI). ${ }^{16}$

Table 3 provides summary statistics for the non-normalized indices. The within-firm scores in Brazil and Korea show substantial variation across time; there is less variation in India and Turkey. ${ }^{17}$

\footnotetext{
13 The original 2006 ICGI used in Balasubramanian, Black, and Khanna (2010) used 49 elements; we lost 7 of these due to need to maintain consistent elements across survey years.

14 We include one RPT-related element (RPTs require board approval) in the Shareholder Rights Subindex.

15 We include two RPT-related elements in the Shareholder Rights Subindex.

${ }^{16}$ Russia also has more limited control variables. We include it in reporting results below only where feasible.

17 The expanded working paper version of this article provides year-by-year data.
} 


\subsection{Comparison to Developed Markets}

Our elements and subindices reflect measures that we judged would likely be important in emerging markets. Different elements would be appropriate in developed markets. For example, BCGI and the 24-element Gompers, Ishii and Metrick (2003) "GIM" index include only three common elements: classified board of directors, dual-class common stock, and take-out rights. Similar, only four elements of BCGI are among the 44 elements of the Institutional Shareholder Services index (see Aggarwal et al., 2009): separate CEO and chair, majority of outside directors, no classified board, and no dual-class common stock. Some non-overlap reflects the limited scope of the GIM and ISS indices, ${ }^{18}$ but most reflects differences between a US-centric index and one appropriate in an emerging market.

\subsection{Commonalities and Differences across Countries}

While we seek to maintain common subindices and elements where feasible, we adapt our governance index to the data available in each country and to country-specific institutions. For example, 18 of the 41 Brazil elements are unique to Brazil. Table 2, which summarizes the elements we use in each country, is mind-numbingly complex. Even more complexity is buried in dozens of footnotes to an offline version, which document details on how elements are coded in different countries and different years. ${ }^{19}$ Still more complexity lurks in different meanings of the same variable in different countries, ${ }^{20}$ and in our judgments about how to define elements. ${ }^{21}$ In that complexity lies a central message of this article. We did our best to build indices that cover similar aspects of governance in each country. At the subindex, we hope that we more-or-less succeeded. Individual elements, however, differ greatly across countries. Table 2 contains 121 elements. Of these, 84 are used in only one country; 25 in two countries ; 8 in three countries, and none are used in all four countries.

Suppose that we built a "Public Index", using elements that are publicly available in all five countries. That index would have only four elements: one board structure element (audit committee

\footnotetext{
18 For criticism of these indices, see Bhagat, Bolton and Romano (2008); Daines, Gow and Larcker (2010).

19 For example, in some countries, we can measure whether a director is "outside"; in others, we can measure whether a director is "independent" (defined somewhat differently in each country). In Korea, we know whether the audit committee has 2/3 outside directors; in India we know whether it has a majority of outside directors. We ignore these and other small differences in meaning, exercising judgment as to what is "small".

20 For example, the element "CEO is NOT chairman of the board" has a very different meaning for a stand-alone firm, where the chair is likely to be an outside director; than for a firm which belongs to a business group, where the chairman often represents the group.

21 In Brazil, for example, a fiscal board can be "permanent" (established in the firm's charter). If not, it can still be called for a particular year by request of $10 \%$ of the shareholders. We coded a firm as "having" a fiscal board if this board was either permanent or had been called in four or five of the last five years.
} 
exists); three disclosure elements (firm discloses 5\% holders; firm has English language financials; financial statements include statement of cash flows); and no elements for the other four subindices. In individual countries, there is even less to the Public Index than the four apparent elements. Consider India. Audit committees are required; all financials are in English and include a statement of cash flows. This leaves one useful element - whether the firm discloses 5\% holders. Even there, usefulness is limited, since disclosure of ownership by the control group is required.

Can educated guessing help? We don't think so. Consider Dahya, Dimitrov and McConnell (2008). When they lack data on which directors are independent, they infer independence based on whether a director is employed by the firm or has the same family name as the controlling family. For Brazil in 2002 , they estimate that $57 \%$ of directors of their sample firms were independent. We find that the mean percentage of outside directors in 2004 is $23 \%$. The difference in percentages is far too large to be explained by different samples. ${ }^{22}$ In our view, their estimate provides mostly noise, not signal.

\subsection{Can We Build An Index with Common Elements?}

We can improve on the Public Index by using private survey data, at the cost of building an index that cannot be replicated in a massively multicountry study. Suppose we ask: which elements are available during our sample period in Brazil, India, Korea, and Turkey, and useful (have meaningful variation) in at least two countries? We use these elements to build a "Common-2 Index." Table 2 indicates the elements of the Public and Common-2 indices.

The Common-2 Index includes 14 elements: 5 in board structure 3 in disclosure, 2 each in board procedure and ownership; and one each for shareholder rights and RPTs. As with the Public Index, only some elements are meaningful in each country. ${ }^{23}$ Of the 13 elements, 11 are useful in three countries; none are useful in all four. As we discuss below, the Common-2 Index has very little predictive value. Moreover, even if we found that it had economic or statistical significance, we could have limited confidence that this significance came from the measured elements, rather than unmeasured elements which were correlated with the measured elements.

\footnotetext{
22 Bovespa has multiple listing levels, with different corporate governance standards. The highest level, Novo Mercado, requires only $20 \%$ independent directors.

23 With substantial data collection effort, we could add three additional "feasible" elements to the Common-2 Index; all within board structure and board procedure. Some additional disclosure elements would be available today, but we don't have them for the periods covered by our study.
} 


\section{Methodology: Construct Validity and Endogeneity Concerns}

\subsection{Embracing Construct Validity}

Prior multicountry studies have used the same index across countries. Given the severe constraints on our ability to build an index with common elements, we adopt a different approach. We abandon the pretense that an index comprised of common elements can capture what's important about governance in each country. We posit instead that there is an underlying, unobserved concept of "overall corporate governance", which can usefully be divided into unobserved "buckets" of board structure, board procedure, disclosure, ownership, shareholder rights, and RPT control; and that each bucket is composed of unobserved "aspects", such as true effectiveness of the board of directors; the audit committee (or a local substitute), and so on. For us, measuring corporate governance involves developing measurable constructs - at the element, subindex, and overall index levels - that map decently onto unobserved true governance. That is, we are measuring constructs (elements) within larger constructs (subindices) within a larger construct (overall country index). The mapping from constructs to underlying governance will depend on local rules and institutions. The unobserved aspects of governance differ across countries; thus, the elements and subindices we construct to capture them must vary as well.

Also, we are interested in the causal question: Will a within-country change in governance change Tobin's $q$, or another outcome variable? Governance levels vary greatly across countries, reflecting a mix of local rules and practices. Only elements with meaningful variation across firms and time are useful in assessing causation. Those elements will also vary substantially across countries.

How will we know whether we have chosen sensible constructs - whether, say, the Brazil governance construct measures something similar to the India construct? A null result could mean either that governance doesn't affect Tobin's $q$ or that we have not measured governance correctly. A result in some countries (but not others) could mean that governance only matters in those countries or that we have built better constructs in those countries. But if we find a positive association across countries, with a broad index and a reasonably strong research design (say firm fixed effects with extensive control variables), this provides evidence both that governance predicts Tobin's $q$ and that our country-specific constructs do a decent job of measuring governance. ${ }^{24}$

\footnotetext{
24 With a broad index and a good research design, it is less likely (though never impossible) that an omitted nongovernance variable explains the association between governance and Tobin's $q$. One would want to "drill down" and assess whether the predictive value of an overall index comes from similar subindices and, to the extent feasible, similar elements. We conduct that drill-down in our companion paper.
} 


\subsection{Regression Specifications}

So onward, to what we do and what we find. Our principal dependent variable is $\ln$ (Tobin's $q$ ). Tobin's $q$ is a common dependent variable in governance-to-value studies. We take logs to reduce the influence of high- $q$ outliers. We also exclude outlier firms, for which a studentized residual from regressing $\ln (q)$ on country CGI (year-by-year for panel regressions) $>|1.96|$. Within each country, we regress $\ln (q)$ on CGI and a vector of control variables, denoted $\mathbf{X}_{\mathrm{i}}$. We use four different models. The first model is cross-sectional, using one year from each country. ${ }^{25}$

$$
\ln Q_{i}=\beta_{0}+\beta_{1} * C G I_{i}+\boldsymbol{\beta}_{2} * \mathbf{X}_{\mathbf{i}}+\varepsilon_{i} \quad \text { Model } 1 \text { (cross-sectional OLS) }
$$

Many single-country studies, and all prior multicountry studies, use only cross-sectional data. One goal of this article is to improve on this specification by using panel data on governance. We use three specifications: pooled OLS, firm random effects (RE), and firm fixed effects (FE). All use standard errors with year dummies, firm clusters, and an unbalanced panel.

$$
\begin{array}{ll}
\ln Q_{i, t}=\beta_{0}+\beta_{1} * C G I_{i, t}+\boldsymbol{\beta}_{2} * \mathbf{X}_{i, t}+g_{t}+\varepsilon_{i, t} & \text { Model 2 (pooled OLS) } \\
\ln Q_{i, t}=\beta_{0}+\beta_{1} * C G I_{i, t}+\boldsymbol{\beta}_{2} * \mathbf{X}_{i, t}+f_{i}+g_{t}+\varepsilon_{i, t} & \text { Model } 3(\mathrm{RE} \text { and FE) }
\end{array}
$$

The FE model provides unbiased estimates even if the firm effects are correlated with other variables, but imposes a substantial loss of sample size. In Brazil, only 72 of the 159 firms in our dataset appear at least twice; in India, only 186 of 399 appear at least twice. Moreover, with FE, we can study only aspects of governance with substantial within-firm time variation. Thus, both RE and FE are useful specifications, with different strengths. ${ }^{26}$

\subsection{Control Variables}

Many firm characteristics are potentially associated with both Tobin's $q$ and governance. We therefore include extensive control variables to reduce omitted variable bias (OVB). Table 4 defines our principal control variables and indicates which is available in each country. We work hard to limit loss of sample size due to missing data through how we define control variables. ${ }^{27}$

\footnotetext{
25 We use the first year with governance data for Brazil (2004), India (2006), and Turkey (2006), 2001 (first year after major reforms) for Korea, and 2003 (year with most observations) for Russia.

26 We discuss in Part 5 additional specifications which pool results across countries. Some studies seek to address endogeneity by instrumenting for governance, Tobin's $q$, or both. We find the instruments unconvincing, and do not pursue this approach here. On concerns with instrumental variables in finance and accounting generally, see Larcker and Rusticus (2010); Roberts and Whited (2011), Atanasov and Black (2013).

27 Some examples: We sometimes impute values from an adjacent year. We generally define leverage as total liabilities/(total liabilities + book value of assets), but use total debt instead of total liabilities in India because in the
} 
We use the following control variables. Firm size: $\ln$ (assets) to control for the effect of firm size on Tobin's q; Firm age: $\ln ($ years listed +1 ), because younger firms are likely to be faster-growing and more intangible asset-intensive, which can lead to higher Tobin's q; Leverage: measured as total liabilities/total assets. Leverage can influence Tobin's $q$ by affecting income taxes benefits and reducing free cash flow problems; it is also mechanically related to Tobin's q. Growth prospects and profitability: Tobin's $q$ is related to a firm's growth prospects and profitability. We control for geometric sales growth over the last 3 years, and for profitability using both net income/assets and EBIT/sales. Capital intensity and asset tangibility: Asset tangibility can both predict Tobin's $q$ and affect what type of governance a firm needs. We control for PPE/sales, capex/PPE, R\&D/sales, and advertising/sales. Liquidity: share turnover (traded shares/total shares) and free float, since share prices may be higher for firms with more liquid shares. Ownership: fractional ownership by the largest shareholder; by foreign investors, and the state. Product market competition, which can substitute for governance in imposing discipline on managers: exports/sales and domestic market share in the firm's principal industry. ${ }^{28}$

\subsection{Endogeneity}

Except for Korea, we have no exogenous shock to governance. ${ }^{29}$ Thus, the different flavors of endogeneity are important concerns. What can be said about how likely our results are to involve causation? Consider reverse causation, with firm value predicting governance, and the optimal differences flavor of endogeneity, with firms choosing their governance to meet firm-specific needs. To limit the extent of reverse causation, we measure governance in the first part of a year and Tobin's $q$ at year-end. Moreover, in individual country studies, time-varying firm characteristics only weakly predict governance. Firm, industry, and business-group effects can be stronger predictors of governance, but our

Prowess database, total liabilities = total assets, for some reason. In Korea, state ownership is missing for 2004; we imputed values from 2003. We drop firm-years with zero or negative sales. In India, we use $\ln ($ years since incorporation) instead of $\ln ($ years listed +1 ), because listing year is not available. For India for 2012, we use the most recent available data (for fiscal 2010, ending March 31, 2011) to compute control variables. Russia controls are more limited than in other countries. See expanded working paper for more details.

28 We also include several variables which drop out with firm fixed effects, but are relevant for other specifications. Industry dummies, defined separately in each country (9 dummies for Brazil, 11 for India, 4-digit Korean SIC codes for Korea, and 2-digit US-equivalent SIC codes for Turkey and "common controls" regressions.). US cross-listing dummy and MSCI index dummy to proxy for liquidity and foreign investor interest. Business group dummy, because group firms may behave differently than stand-alone firms.

29 In Korea, large firms (assets $>2$ trillion won) face a legal shock to governance which comes into force in 2000 2001, during our study period; we study that shock elsewhere (black, Jang and Kim, 2006; Black and Kim, 2012). 
FE and (less strongly, RE) specifications address these. ${ }^{30}$ The most important endogeneity concern is likely to be omitted variables which are associated with both governance and Tobin's $q$. Here, firm fixed effects and extensive controls help; as does a broad governance index, which is less likely to be accidentally associated with a particular omitted variable.

\section{Country-Level Results}

\subsection{Cross-Sectional and Pooled OLS}

In Table 5, we examine the association between country governance and Tobin's $q$, across countries and regression models. In each panel, we report the coefficient on country CGI and suppress the coefficients on the control variables. Panel 1 presents pure cross-sectional OLS results, using only one year for each country. ${ }^{31}$ In each country, higher CGI predicts higher Tobin's $q$, by economically meaningful amounts. In Brazil, for example, the 0.150 coefficient implies that a one-standard-deviation increase in BCGI predicts an $16 \%$ increase in $\ln$ (Tobin's $q$ ).

Yet the apparent consistency is deceiving. We show year-by-year, cross-sectional OLS results in Table 6. We show results for each year for Brazil and India, and an early year, a middle year, and the last sample year for other countries. In each country, the coefficient on CGI is significant in some years, yet insignificant in others, and (except in Russia) sometimes negative. In India, for example, we find a significant $0.107(t=2.09)$ coefficient for 2006, but the coefficient for 2007 is 0.000 and for 2012 is 0.058 (both insignificant). In Brazil, the coefficient on BCGI is significant in 2004 at $0.150(t=3.10)$, but insignificant in 2006 (coeff. $=0.073 ; \mathrm{t}=1.22)$ and 2009 (coeff. $=0.062, t=1.43$ ).

Subindex level results (presented in our companion paper) provide further reason for concern with the reliability of cross-sectional results. If we include each subindex separately in a regression otherwise similar to Table 5, panel 1, the significant subindices are board structure (Brazil and Korea) disclosure (Korea and Turkey), RPTs (Brazil), and shareholder rights (Turkey). We found the opposite (negative) sign on board structure for Brazil in Black, de Carvalho and Gorga (2012), using the same governance data and a similar specification. ${ }^{32}$ For Brazil, the sign on RPT Subindex flips with pooled OLS. For Turkey, the results for Shareholder Rights Subindex survive with random effects, but vanish

30 See Black and Kim (2012) (Korea); Balasubramanian, Black and Khanna (2010) (India); Ararat, Black and Yurtoglu (2013) (Turkey).

31 We use the first available year in Brazil, India, and Turkey. In Korea, we use 2001 (just after the large firm reforms come into effect). In Russia, we use 2003, where we have the most complete data.

32 We discuss this puzzling result (opposite signs from very similar specifications) in our companion paper. A major reason: When firms restate prior year financial results, the Economatica database revises the prior year numbers. Black, de Carvalho and Gorga (2012) use the original numbers; here we use the revised numbers. 
with fixed effects. Our conclusion: Single-year cross-sectional regressions are not a reliable basis for inferring much of anything about corporate governance in emerging markets.

Panel 2 of Table 5 presents pooled OLS results. Pooled OLS is still a weak specification because it ignores firm effects; we present it largely for comparison to the pure cross-sectional results in Panel A and the firm random effects and fixed effects results in Panels 3 and 4. The coefficients on country CGI become smaller for all countries except Russia, and become insignificant in India. At the same time, $t$ statistics rise in several countries due to larger sample size.

\subsection{Firm Random and Fixed Effects}

We present firm random effects results in Table 5, Panel 3. Country CGI positively and significantly predicts Tobin's $q$ in all countries. A Breusch-Pagan test strongly rejects the absence of firm effects, and implies that pooled OLS will be biased. At the same time, a Hausman test rejects the equivalence of RE and FE models. ${ }^{33}$ The median "lambda", indicating whether RE results are closer to pooled OLS $(\lambda=0)$ or to $\operatorname{FE}((\lambda=1)$ is low for Brazil at 0.33 and India at 0.30 , but higher for Korea and Turkey, which have more data years and a more balanced panel, at 0.63 in Korea and 0.66 in Turkey.

The Hausman test results suggest that both pooled OLS and RE results are likely to be biased. In our experience, RE coefficients are often in between pooled OLS and FE; this is the case for all countries except Brazil (where we lose many firms in the FE specification). If so, and especially if $\lambda$ is close to 1 , it $\mathrm{RE}$ is likely less biased than pooled OLS. This is an opinion, informed by experience, not a theorem. ${ }^{34}$

In Panel 4, with fixed effects, the results generally weaken. Coefficients drop in all countries except India and $t$-statistics drop in all countries. The coefficients remain significant in India, Korea, and Russia, and are marginally significant in Turkey, but become insignificant in Brazil. This weakening likely reflects a combination of bias in the RE coefficients, loss of sample size, and limited within-firm variation. There is no easy way to assess the relative contribution of each factor.

The coefficients on CGI in Table 5 are economically important and have plausible magnitudes. For example, the significant FE coefficients range from 0.045 to 0.075 . This implies that a one-standarddeviation increase in governance predicts a 4.6-7.8\% increase in Tobin's $q$.

\footnotetext{
33 We treat the Hausman test results as merely suggestive. The test only runs in three countries (Brazil, Korea, and Turkey), is unreliable in Brazil due to a highly unbalanced panel, and does not allow for clustered standard errors.

34 We are aware of no simulation or other research that assesses the likely relative bias of pooled OLS versus firm random effects in situations where firm fixed effects results may be unreliable.
} 


\subsection{Robustness to Choice of Control Variables}

In Table 7, we present robustness checks for Brazil, India, Korea, and Turkey using RE and FE, with different specifications for control variables and the dependent variable. All specifications are the same as in Table 5, except as indicated. Panel 1 reproduces our base specification from Table 5. In Panels 2-5 we vary the control variables. In Panel 2, we use a common set of controls instead of countryspecific controls. This principally means dropping several variables that we lack in Brazil. The India and Korea results strengthen, suggesting that even with FE, extensive time-varying controls are needed to limit OVB. In Panel 3, we return to country-specific controls, but winsorize the control variables. This has little impact, relative to Panel 1. In Panel 4, we use a limited set of control variables, similar to those used in Dahya, Dimitrov and McConnell (2008). ${ }^{35}$ Relative to Panel 2, the coefficients change somewhat in India and Korea, but strongly in Turkey, where FE results go from barely significant (coeff. $=.050 ; t=$ 1.88 ) to easily so (coeff. $=0.068 ; t=2.48$ ). In Panel 5 , we use a still smaller set of control variables, similar to those used in Durnev and Kim (2005). ${ }^{36}$ The Turkey results strengthen further (coeff. $=.077, t$ $=2.70$ ). And the Brazil FE coefficient leaps from 0.088 (insignificant) to 0.162 (strongly significant, $t=$ 3.79). Sensitivity to choice of controls increases if we use pooled OLS instead of RE or FE. ${ }^{37}$

We conclude that there is clear need for governance researchers to use extensive control variables and report the sensitivity of results to choice of controls. At the same time, the coefficients on country CGI do not vary greatly with modest variations in our full set of controls. The changes across Panels 1-3 are largest in Korea (FE coefficients range from [0.44, 0.55] depending on control variables). The relative stability of these estimates suggests that if one uses panel data with FE or RE, a reasonable number of time periods, and extensive firm-level controls, it is plausible that remaining OVB will be limited.

\subsection{Robustness to Choice of Dependent Variable}

In the remaining panels of Table 7, we vary the specification of the dependent variable. In Panel 6 , instead of excluding outliers, we winsorize $\ln (q)$. Compared to Panel 1 , the results strengthen in Turkey but weaken in other countries. In India, we lose significance for both RE and FE; the FE

\footnotetext{
35 The controls in Panel 4 are $\ln ($ assets; $\ln ($ years listed + 1); sales growth; PPE/sales; R\&D/sales (n.a. in Brazil); exports/sales (n.a. in Brazil); 2-digit US SIC industry dummies; cross-listing dummy; year dummies.

36 The controls in Panel 5 are ln(assets; R\&D/sales (not available in Brazil); exports/sales (not available in Brazil); country-specific industry dummies; cross-listing dummy; year dummies.

37 For example, in Korea, the increase in the coefficient on KCGI if we use limited controls, relative to the base specification, is +.0037 for FE ( $8 \%$ ), but grows to +.0086 for RE (18\%); and +.0256 for pooled OLS (49\%). Thus, the weak results from these specifications are further weakened with limited controls.
} 
coefficient drops from .075 to only .015. In Brazil, the RE results become only marginally significant. In Panel 7, we neither winsorize nor exclude outliers. Results are slightly weaker than in Panel 6. In Panel 8 , we use non-logged Tobin's $q$ as the dependent variable, but exclude outliers. The results weaken again; only in Korea are the coefficients still statistically significant. In Panel 9, we switch to $\ln$ (market/book) as dependent variable, and exclude outliers. Significance is similar to our base specification in Brazil, India, and Korea, but FE is insignificant for Turkey. The overall message: How one defines the dependent variable and handles outliers can have a major impact on results.

\section{Pooled Regressions across Countries}

\subsection{Pooled Index Results}

We assess in Table 8 what results we would get if we treated our distinct country indices as if they capture the same underlying construct. We combine CGI scores across Brazil, India, Korea, and Turkey into a "Pooled CGI", and use this pooled index to predict Tobin's $q$ for a sample which includes all four countries. In Panels 1-4, we use specifications similar to Table 5: cross-sectional OLS using selected years for each country; pooled OLS; RE; and FE. We use winsorized control variables and, of necessity, only common control variables. Cross-sectional OLS includes country fixed effects; other specifications include year*country fixed effects. In Panel 5, we use FE plus a stronger specification for controls, by interacting each with country dummies. In OLS and FE specifications, we weight results from each country by 1 (number of firms), thus giving roughly equal weight to each country. Weights are not available for RE. We present the RE and FE specification below. Letting $c$ index countries, $d_{c}$ be country dummies, and suppressing the FE weights, the RE/FE specification is:

$$
\ln Q_{c, i, t}=\beta_{0}+\beta_{1} * C G I_{c, i, t}+\boldsymbol{\beta}_{2} * \mathbf{X}_{c, i, t}+f_{i}+\left(g_{t} * d_{c}\right)+\varepsilon_{c, i, t} \quad \text { Model 3-cc }
$$

In column (1), Pooled CGI is strongly significant across models, with similar coefficients across Panels 2-5, in which we pool data across years. ${ }^{38}$ This suggests that our country indices are capturing something about governance that affects firm market value. This, in turn, might justify combining scores from country-CGI indices that are broadly similar at the subindex level, but quite different at the element level, into pooled CGI.

\footnotetext{
38 A Breusch-Pagan test continues to strongly reject the absence of firm effects. Median $\lambda$ is 0.72 , suggesting that RE may be an acceptable specification, albeit unweighted.
} 


\subsection{Common-2 and Non-Common CGI Indices}

We next build the Common-2 Index, and assess what it predicts. Recall from Section 2.5 that this index uses 14 elements which have data available in all four countries and which we judged to be useful in at least two countries. We build country-level Comon-2 indices and a multicountry Common-2 Index following the same procedure as for overall CGI. ${ }^{39}$

Table 8, column (2) provides results for multicountry Common-2 Index. This index takes a positive and significant coefficient for a pure cross-sectional OLS regressions in Panel 1 -- to which, as discussed above, we assign little value. But the Common-2 Index drops in magnitude and becomes only barely significant with pooled OLS; drops further in magnitude with random effects, and becomes trivially small and insignificant with fixed effects (coeff. $=0.005 ; t=0.32$ ). Thus, there is only very weak evidence that the best common index we can build predicts firm market value.

We next assess the relative power of the common and non-common governance elements to predict Tobin's $q$. We adopt two approaches. First, we build "reduced" country indices, composed solely of non-common elements, and a multicountry "Non-common CGI", using the same process as for the full indices. In column (3), we include Common-2 Index and Non-Common CGI in the same regression. Non-common CGI is statistically and economically strong across specifications. In contrast, the coefficient on Common-2 Index is close to zero, never close to significant, and has mixed signs in the three pooled models. In effect, Common-2 Index has no predictive power, separate from Non-common CGI. Its power in column (2) can be seen as reflecting OVB, due to the 0.36 correlation between Common-2 Index and (omitted) Non-common CGI), which predicts Tobin's $q$.

This reinforces a point made in the Introduction. There can be severe construct validity (and related OVB) concerns for a governance measure that - like our Common-2 Index - is relatively narrow and not tailored to country-specific norms and rules. This concern was part of why we built broad, country specific indices, to better capture what about governance is likely to matters in each country.

In column (4), we assess the relative power of the common and country-specific governance elements in a somewhat different manner, by includingCommon-2 Index and Pooled CGI in the same regression. The coefficient on Common-2 Index (Pooled CGI) provides an estimate of the power of the part of Common-2 Index (Pooled CGI) that is orthogonal to Pooled CGI (Common-2 Index) to predict Tobin's $q$, conditioned on controls. Pooled CGI remains strong, with coefficients similar to column 1,

\footnotetext{
39 If a subindex has no usable elements in a particular country, we drop it, and compute the country index using the remaining subindices. For example, RPT Subindex includes one element, for "RPTs require board approval." In Turkey, this element is legally required, so we cannot construct this subindex.
} 
where it was included alone. In contrast, the coefficients on Common-2 Index are negative in all specifications, and marginally significantly so with RE. Taken together, the results in columns (3) and (4) provide strong evidence that what matters about corporate governance is captured by the non-common, country-specific elements, not by the common ones.

We also examine the power of Common-2 Index in each country. The last two rows of Table 3 show within-country correlation coefficients between (i) Common-2 Index and CGI; and (ii) Common-2 Index and Non-common Index. The correlations with CGI range from 0.50 to 0.75 , but some of this correlation is mechanical, because the Common-2 and country indices include some common elements. The correlations between Common-2 Index and Non-common CGI do not have this problem; they range from .26 in India to 0.62 in Korea. The higher correlation in Korea suggests more severe OVB if the Common-2 Index were used alone in Korea. ${ }^{40}$

We present coefficients on country Common-2 Index in the last row of Table 7. The coefficients in Brazil, India, and Turkey are small and insignificant for both RE and FE. In Korea, Common-2 Index is significant with RE, but insignificant with FE. In pooled OLS results (not reported), Common-2 Index is again significant only in Korea. This is a further caution sign for a common index: Such results as one finds could be driven by a small number of countries. One can only tell by examining results in each country. To reinforce this point, we return to the pooled approach in Table 8 but drop Korea from the sample. The coefficients on Common-2 Index become small and insignificant in all specifications; for example, the RE coefficient is $0.006(t=0.33)$.

\subsection{Revisiting Prior Studies}

With the weak results for cross-sectional OLS and for Common-2 Index in mind, we revisit three well-known, massively multicountry studies, which use the common index approach: Klapper and Love (2004); Durnev and Kim (2005); and Dahya, Dimitrov and McConnell (2008). These studies are often seen as providing evidence that firm-level governance predicts higher firm value. ${ }^{41}$

\footnotetext{
${ }^{40}$ The Korea correlation could also suggest greater construct validity for Common-2 Index. To distinguish between the two, we run country-level regressions, similar to Table 8, columns (3) and (4). For Korea, Non-common CGI and overall CGI remain strong; in contrast, Non-common CGI is insignificant in all cases and takes a negative coefficient in RE and FE regressions similar to Table 8, column (4). This suggests that OVB, rather than partial construct validity, is driving the RE coefficient on Common-2 Index, when included alone.

${ }^{41}$ Our goal is to assess the robustness of results, not to criticize these articles. All were pioneering efforts when written. Klapper and Love (2004) and Durnev and Kim (2005) are concerned as much with what predicts governance as with whether governance predicts firm market value. Dahya, Dimitrov and McConnell conduct several of the robustness checks we suggest here. Moreover, early efforts can take approaches that would be questioned later on; and many papers written some time ago use methods that would be seen as suboptimal today.
} 
Klapper and Love (2004) report evidence that the Credit Lyonnais Securities Asia (CLSA) crosscountry index for 2001 predicts higher Tobin's $q$ and ROA, with $t$-values around 2.75. However, the CLSA index includes some subjective elements, scored by their analysts. ${ }^{42}$ Higher market valuations could affect those scores. They have only a few controls (ln(sales), sales growth, PPE/sales, country dummies, and 1-digit industries). Durnev and Kim (2005) use winsorized Tobin's $q$ as their dependent variable. Their firm-level controls are limited ( $\ln ($ sales), sales growth, R\&D/sales, exports/sales, US cross-listing, consolidated financials); they use country random effects and include several developed countries in their sample (Australia, Japan, New Zealand, Singapore). They find the CLSA index from 2001 and the S\&P Transparency and Disclosure Index from 2000 predict higher Tobin's $q$, but weakly with p-values of 0.06 for the CLSA index and 0.04 for S\&P.

Dahya, Dimitrov and McConnell (2008) study the association between board independence and market value, proxied by raw Tobin's $q$, for firms with a controlling shareholder. For some countries, they guess which directors are independent; we discuss above why this is problematic. Their control variables are better than Klapper and Love or Durnev and Kim, but still limited. Their p-values with country fixed effects range from $[.02, .10]$. Their power comes from the markets with lower scores on a legal protection index and, in significant part, from India. This is consistent with our view that firms in different markets may need different governance rules ${ }^{43}$ We conclude that our weak results for the Common-2 Index are not inconsistent with these studies. They have somewhat stronger $t$ - and $p$-values, but weaker specifications, in ways that, as we show above, can strongly affect results.

\section{Conclusion}

The methodology goal of this article was to highlight and then address the challenges involved in cross-country assessments of what matters in corporate governance. The core, related challenges in emerging markets are construct validity and lack of governance data, especially time-series data. We address these by building country-specific indices, each of which relies heavily on hand-collected data. Important data challenges remain. For example, we build a Disclosure Subindex in each country, but the number of elements varies from three in Korea to 21 in Turkey. We are unable to build a meaningful RPT Subindex in Korea or in Turkey.

Our results confirm the centrality of construct validity concerns. Country-specific indices have power to predict Tobin's $q$, both in each country and if pooled across countries. In contrast, an index

\footnotetext{
42 See Khanna, Kogan and Palepu (2006) for further discussion of the CLSA index.

43 In unreported regressions, we find an insignificant coefficient on India Board Structure Subindex in regressions which include other subindices. This suggests an OVB explanation for the Dahya et al. India results.
} 
comprised of common elements predicts Tobin's $q$ hardly at al. It has predictive power only in Korea, and even there loses power with FE. Moreover, in a horse race between the common index and an index comprised of non-common elements, the common index has no predictive power. Its apparent power in Korea thus likely reflects OVB, due to correlation between the common and non-common indices.

Endogeneity, principally omitted variable bias, is a third major concern; we confirm its importance and address it by using a broad governance index, panel data with FE or RE and extensive control variables. Sensitivity to specification is important and often underexamined; we respond by varying our regression models, control variables, and how we define the dependent variable. Taking these concerns together, the results from prior multicountry studies, which use simple cross-sectional OLS, governance indices built from common elements, and limited control variables, are simply not reliable.

Our substantive goal was to assess, in a cross-country framework, whether firm-level variation in corporate governance predicts firm-level variation in market value. For that goal, country-specific indices, tailored to local rules and institutions, have substantial predictive power. More tentatively, it may be possible to pool indices, which seek to measure similar underlying constructs in different, countryspecific ways, to develop meaningful cross-country governance measures.

\section{References}

Aggarwal, Reena, Isil Erel, Rene M. Stulz, and Rohan Williamson (2009), Differences in Governance Practices Between U.S. and Foreign Firms: Measurement, Causes, and Consequences, Review of Financial Studies 22, 3131-3169.

Ararat, Melsa, Hakan Orbay, and B. Burcin Yurtoglu (2010), "The Effects of Board Independence in Controlled Firms: Evidence from Turkey", working paper.

Ararat, Melsa, Bernard Black, and B. Burcin Yurtoglu (2013), Corporate Governance, Business Groups, and Market Value: Time-Series Evidence from Turkey, working paper, at http://ssrn.com/abstract=2xxxxxx.

Atanasov, Vladimir, Bernard Black, Conrad Ciccotello, and Stanley Gyoshev (2010), How Does Law Affect Finance? An Examination of Equity Tunneling in Bulgaria, Journal of Financial Economics 96, 155-173.

Vladimir Atanasov and Bernard Black (2013), Shock-Based Causal Inference in Corporate Finance Research, working paper, at http://ssrn.com/abstract=1718555.

Bae, Kee-Hong, Jon-Koo Kang, and Jin-Mo Kim (2002), Tunneling or Value Added? Evidence from Mergers by Korean Business Groups, Journal of Finance 57, 2695-2740.

Balasubramanian, N., Bernard Black, and Vikramaditya Khanna (2010). Firm-Level Corporate Governance in Emerging Markets: A Case Study of India, Emerging Markets Review 11, 319-340.

Bebchuk, Lucian, Alma Cohen, and Allen Ferrell (2009), What Matters in Corporate Governance?, Review of Financial Studies 22, 783-827.

Bebchuk, Lucian Arye, and Assaf Hamdani (2009), "The Elusive Quest for Global Governance Standards", 157 University of Pennsylvania Law Review 1263-1316. 
Bennedsen, Morten, Kasper Meisner Nielsen and Thomas Vester Nielsen (2012), "Private Contracting and Corporate Governance: Evidence from the Provision of Tag-Along Rights in Brazil," Journal of Corporate Finance 18, 904-918.

Bertrand, Marianne, Paras Mehta, and Sendhil Mullainathan (2002), Ferreting Out Tunneling: An Application to Indian Business Groups, Quarterly Journal of Economics 117, 121-148.

Bhagat, Sanjai, Brian Bolton, and Roberta Romano (2008), The Promise and Perils of Corporate Governance Indices, Columbia Law Review 108, 1803-1882.

Black, Bernard (2001), “The Corporate Governance Behavior and Market Value of Russian Firms,"2 Emerging Markets Review 89-108.

Black, Bernard, Antonio Gledson de Carvalho, and Erica Gorga (2010), "Corporate Governance in Brazil”, 11 Emerging Markets Review, vol. 11, 21-38.

Black, Bernard, Antonio Gledson de Carvalho, and Erica Christina Rocha Gorga (2012), "What Matters and for Which Firms for Corporate Governance in Emerging Markets?: Evidence from Brazil (and Other BRIK Countries)" 18 Journal of Corporate Finance 934-952.

Black, Bernard, Antonio Gledson de Carvalho and Joelson Sampaio (2012), "The Evolution of Corporate Governance in Brazil”, working paper, at http://ssrn.com/abstract=2181039.

Black, Bernard, Antonio Gledson de Carvalho, Vikramaditya Khanna, Woochan Kim, and Burcin Yurtoglu (2013a), What Aspects of Corporate Governance Appear to Create Value in Emerging Markets, working paper, at http://ssrn.com/abstract $=2227718$.

Black, Bernard, Antonio Gledson de Carvalho, Vikramaditya Khanna, Woochan Kim, and Burcin Yurtoglu (2013b), Perils in Multicountry Studies of Corporate Governance: Time-Series Evidence from the BRIKT Countries (Brazil, Russia, India, Korea, Turkey) (working paper with expanded appendices), at $\mathrm{http}: / / \mathrm{ssrn} . \mathrm{com} / \mathrm{abstract}=2 \mathrm{xxxxx}$.

Black, Bernard, Hasung Jang and Woochan Kim (2006a), Does Corporate Governance Affect Firms' Market Values? Evidence from Korea, Journal of Law, Economics and Organization 22, 366-413.

Black, Bernard, and Vikramaditya Khanna (2007), "Can Corporate Governance Reforms Increase Firms' Market Values? Event Study Evidence from India," 4 Journal of Empirical Legal Studies 749-796.

Black, Bernard, and Woochan Kim (2012), The Effect of Board Structure on Firm Value: A Multiple Identification Strategies Approach Using Korean Data, Journal of Financial Economics 104, 203-226.

Black, Bernard Woochan Kim, Hasung Jang \& Kyung-Suh Park (2013), How Corporate Governance Affects Firm Value: Evidence from Korea on a Related Party Transactions Channel, working paper, at http://ssrn.com/abstract=844744.

Black, Bernard, Inessa Love and Andrei Rachinsky (2006), Corporate Governance Indices and Firms' Market Values: Time-Series Evidence from Russia, Emerging Markets Review 7, 361-379.

Claessens, Stijn, Simeon Djankov, Joseph Fan, and Larry Lang (2002), Disentangling the Incentive and Entrenchment Effects of Large Shareholdings, Journal of Finance 57, 2741-2771.

Claessens, Stijn, and Burcin Yurtoglu (2013), Corporate Governance in Emerging Markets: A Survey, Emerging Markets Review, forthcoming.

Dahya, Jay, Orlin Dimitrov, and John J. McConnell (2008), Dominant Shareholders, Corporate Boards, and Corporate Value: A Cross-Country Analysis,” Journal of Financial Economics 87, 73-100.

Daines, Robert, Ian Gow, and David Larcker (2010), Rating the Ratings: How Good are Commercial Governance Ratings?, Journal of Financial Economics 98, 439-461.

De Carvalho, Antonio Gledson, and George G. Pennacchi (2012), Can a Stock Exchange Improve Corporate Behavior? Evidence from Firm's Migration to Premium Listings in Brazil, Journal of Corporate Finance. $18,883-903$. 
Dharmapala, Dhammika, and Vikramaditya Khanna (2013), "Corporate Governance, Enforcement and Firm Value: Evidence from India", Journal of Law, Economics and Organization (forthcoming), working paper at http://ssrn.com/abstract=1105732.

Doidge, Craig, G. Andrew Karolyi and Rene M. Stulz (2007), Why Do Countries Matter So Much for Corporate Governance," Journal of Financial Economics 86, 1-39.

Durnev, Artyom, and E. Han Kim (2005), To Steal or Not to Steal: Firm Attributes, Legal Environment, and Valuation, Journal of Finance 60, 1461-1493.

Glaeser, Edward, Simon Johnson, and Andrei Shleifer (2001), Coase Versus the Coasians, Quarterly Journal of Economics 108, 853-899.

Gompers, Paul, Joy Ishii, and Andrew Metrick (2003), Corporate Governance and Equity Prices, Quarterly Journal of Economics 118, 107-155.

Khanna, Tarun, Joe Kogan, and Krishna Palepu (2006), Globalization and Similarities in Corporate Governance: A Cross-Country Analysis, Review of Economics and Statistics 88, 69-90.

Klapper, Leora F., and Inessa Love (2004), Corporate Governance, Investor Protection and Performance in Emerging Markets, Journal of Corporate Finance 10, 703-728.

La Porta, Rafael, Florencio Lopez-de-Silanes and Andrei Shleifer (1998a), Corporate Ownership Around the World, Journal of Finance 54, 717- 738.

La Porta, Rafael, Florencio Lopez-de-Silanes, Andrei Shleifer and Robert Vishny (1997), Legal Determinants of External Finance, Journal of Finance 52, 1131-1150.

La Porta, Rafael, Florencio Lopez-de-Silanes, Andrei Shleifer and Robert Vishny (1998b), Law and Finance, Journal of Political Economy 106, 1113-1155.

Larcker, David F., and Tjomme O. Rusticus (2010), On the Use of Instrumental Variables in Accounting Research, 49 Journal of Accounting and Economics 186-205.

Levine, Ross, and Sara Zervos (1998), Stock Markets, Banks, and Economic Growth, American Economic Review $88,537-558$.

Morey, Matthew, Aron Gottesman, Edward Baker, and Ben Godridge (2009), Does Better Corporate Governance Result in Higher Valuations in Emerging Markets? Another Examination Using a New Data Set, Journal of Banking and Finance 33, 254-262.

Roberts, Michael R., and Toni M. Whited, 2011, Endogeneity in Empirical Corporate Finance, working paper, at http://ssrn.com/abstract=1748604 (forthcoming, Handbook of the Economics of Finance).

OECD (Organisation for Economic Co-operation and Development) (2004), Principles of Corporate Governance.

Shadish, William, Thomas Cook, and Donald Campbell (2002), Experimental and Quasi-Experimental Designs for Generalized Causal Inference. 
Table 1.

Brazilian sample.

\begin{tabular}{ccccc}
\hline Number of firms & All public firms & $\begin{array}{c}\text { Responding } \\
\text { firms }\end{array}$ & $\begin{array}{c}\text { Market cap } \\
\text { (US\$ billions) }\end{array}$ & $\begin{array}{c}\text { Capitalization of } \\
\text { responding firms }\end{array}$ \\
2004 & 261 & $63(24 \%)$ & 524 & $260(49 \%)$ \\
2006 & 233 & $92(39 \%)$ & 821 & $495(60 \%)$ \\
2009 & 254 & $97(38 \%)$ & 1,191 & $747(62 \%)$ \\
$2004 \& 2006$ & 254 & 28 & 1,191 & \\
$2004 \& 2009$ & 254 & 21 & 1,191 & \\
$2006 \& 2009$ & 254 & 53 & 1,191 & $854(72 \%)$ \\
all 3 surveys & 254 & 17 & 1,191 & \\
at least one survey & 254 & $142(56 \%)$ & & \\
\hline
\end{tabular}

Note: Total number of firms and market capitalization for all firms which responded to the 2004, 2006 and 2009 Brazil corporate governance surveys. Market capitalization is based on exchange rate at Dec. 31, 2009 of $\mathrm{R} \$ 1.75 / \mathrm{US} \$ 1$. Market capitalization and number of Brazilian private firms is measured at end of survey year (for "overlap" rows, most recent year). Last row indicates respondents that were public in 2009 and were in the dataset in at least one year. All data excludes state-controlled firms, banks, and subsidiaries of foreign companies. 
Table 2.

Governance elements in each country and potential common index elements.

\begin{tabular}{|c|c|c|c|c|c|c|}
\hline ELEMENTS & BRAZIL & INDIA & KOREA & TURKEY & LABEL & $\begin{array}{l}\text { COMMON } \\
\text { INDEX-2 } \\
\end{array}$ \\
\hline Years & $2004,06,09$ & 2006, 07, 12 & 1998-2004 & 2006-11 & & \\
\hline \multicolumn{7}{|l|}{ Board Structure Subindex } \\
\hline$\geq 1$ outside director & $\mathrm{X}(\mathrm{NP})$ & required & required & $\mathrm{X}$ & bs_1 & $\mathrm{X}$ \\
\hline$>1$ outside director & avail (NP) & & & $\mathrm{X}$ & bs_2 & \\
\hline$\geq 30 \%$ outside directors & $\mathrm{X}(\mathrm{NP})$ & required & common & avail & bs_3 & $\mathrm{X}$ \\
\hline$\geq 50 \%$ outside directors & $\mathrm{X}(\mathrm{NP})$ & $\mathrm{X}$ & $\mathrm{X}$ & rare & bs_4 & \\
\hline$>50 \%$ outside directors & rare $(\mathrm{NP})$ & $\mathrm{X}$ & $\mathrm{X}$ & rare & bs_5 & $\mathrm{X}$ \\
\hline CEO is board member & common $(\mathrm{F})$ & common $(\mathrm{F})$ & common $(\mathrm{F})$ & $\mathrm{X}$ & bs_7 & \\
\hline CEO is NOT board chairman & $\mathrm{X}$ & $\mathrm{X}$ & avail (NP) & $\mathrm{X}$ & bs_8 & $\mathrm{X}$ \\
\hline Board has outside chair or lead director & NA & feas (NP) & $\mathrm{X}$ & rare & bs_9 & \\
\hline $\begin{array}{l}\geq 50 \% \text { outside directors or } \geq 1 / 3 \text { outside directors } \\
\& \text { and } \mathrm{CEO} \text { is not chairman }\end{array}$ & feas (NP) & $\mathrm{X}$ & avail (NP) & rare & bs_10 & \\
\hline Firm has outside CEO & NA & feas & feas & $\mathrm{X}$ & bs_11 & -- \\
\hline Audit committee & $\mathrm{X}$ & required & $\mathrm{X}$ & required & bs_13 & PUB \\
\hline Audit committee has non-executive chair & NA & feas (NP) & common $(\mathrm{F})$ & $\mathrm{X}$ & bs_14 & \\
\hline Audit committee has outside director & avail (NP) & feas (NP) & common $(\mathrm{F})$ & $\mathrm{X}$ & bs_17 & $\mathrm{F}$ \\
\hline Audit committee has majority of outside directors & rare (NP) & $\mathrm{X}$ & $\mathrm{X}$ & NA & bs_18 & $\mathrm{F}$ \\
\hline Compensation committee & rare $(\mathrm{NP})$ & $\mathrm{X}$ & $\mathrm{X}$ & NA & bs_21 & \\
\hline Outside director nominating committee & rare $(\mathrm{NP})$ & NA & $\mathrm{X}$ & NA & bs_22 & \\
\hline Corporate governance committee & rare $(\mathrm{NP})$ & NA & rare $(\mathrm{F})$ & $\mathrm{X}$ & bs_23 & \\
\hline Fiscal board exists & $\mathrm{X}(\mathrm{NP})$ & NM & NM & NM & bs_24 & \\
\hline $\begin{array}{l}\text { Permanent fiscal board or audit committee has } \\
\text { minority shareholder representative }\end{array}$ & $\mathrm{X}(\mathrm{NP})$ & NM & NM & NM & bs_25 & \\
\hline \multicolumn{7}{|l|}{ Board Procedure Subindex } \\
\hline$\geq 4$ board meetings in last year & $\mathrm{X}(\mathrm{NP})$ & avail (NP) & $\mathrm{X}$ & avail & bp_3 & $\mathrm{X}$ \\
\hline Average board attendance rate $\geq 80 \%$ & common (NP) & not avail & feas & NA & bp_4 & \\
\hline Firm has system to evaluate CEO & $\mathrm{X}(\mathrm{NP})$ & $\mathrm{X}$ & NA & NA & bp_5 & \\
\hline Firm has system to evaluate other executives & $\mathrm{X}(\mathrm{NP})$ & $\mathrm{X}$ & NA & NA & bp_6 & \\
\hline Firm evaluates nonexecutive directors & avail (NP) & $\mathrm{X}$ & $\mathrm{X}(\mathrm{NP})$ & NA & bp_7 & \\
\hline Firm has succession plan for CEO & avail (NP) & $\mathrm{X}$ & NA & NA & bp_8 & \\
\hline Firm has nonexecutive director retire age & NA & $\mathrm{X}$ & rare $(\mathrm{F})$ & NA & bp_9 & \\
\hline Directors receive regular board training & NA & $\mathrm{X}$ & NA & NA & bp_10 & \\
\hline Nonexecutives-only annual board meeting & NA & $\mathrm{X}$ & rare $(\mathrm{F})$ & NA & bp_11 & \\
\hline Outside directors-only annual board meeting & rare $(\mathrm{NP})$ & rare $(\mathrm{NP})$ & $\mathrm{X}$ & NA & bp_12 & \\
\hline Board receives materials in advance & $\mathrm{X}(\mathrm{NP})$ & $\mathrm{X}$ & NA & NA & bp_13 & \\
\hline Nonexecutives can hire counsel, advisors & NA (NP) & $\mathrm{X}$ & NA & NA & bp_14 & \\
\hline Firm has code of ethics & $\mathrm{X}(\mathrm{NP})$ & $\mathrm{X}$ & feas (NP) & $\mathrm{X}$ & bp_15 & $\mathrm{F}$ \\
\hline Bylaw/policy to govern board & $\mathrm{X}(\mathrm{NP})$ & not avail & $\mathrm{X}(\mathrm{NP})$ & $\mathrm{X}$ & $\mathrm{bp} \_16$ & \\
\hline Directors' votes recorded in board minutes & avail (NP) & avail (NP) & $\mathrm{X}(\mathrm{NP})$ & NA & bp_17 & \\
\hline Firm has foreign outside director & rare $(\mathrm{NP})$ & avail (NP) & $\mathrm{X}$ & avail & bp_18 & $\mathrm{X}$ \\
\hline Shareholders approve outside directors' pay & NA & rare $(\mathrm{NP})$ & $\mathrm{X}(\mathrm{NP})$ & NA & bp_22 & \\
\hline Outside directors attend min. $\%$ of meetings & NA & avail (NP) & $\mathrm{X}(70 \%)$ & NA & bp_23 & \\
\hline Firm has internal audit/control function & NA & avail (NP) & required & $\mathrm{X}$ & bpa_1 & \\
\hline Audit committee membership disclosed & NA & avail (NP) & required & $\mathrm{X}$ & bpa_2 & \\
\hline Bylaw to govern audit committee & avail (NP) & $\mathrm{X}$ & $\mathrm{X}(\mathrm{NP})$ & NA & bpa_3 & \\
\hline Company discloses audit committee bylaws & NA & NA & feas & $\mathrm{X}$ & bpa_4 & \\
\hline Audit committee recommends external auditor & NA & $\mathrm{X}$ & NA & NA & bpa_5 & \\
\hline Outside directors on audit comm meet separately & NA & $\mathrm{X}$ & NA & NA & bpa_6 & \\
\hline Audit committee includes acc'g or finance expert & avail (NP) & required & $\mathrm{X}(\mathrm{NP})$ & NA & bpa_9 & \\
\hline Audit committee approves internal audit head & NA & avail (NP) & $\mathrm{X}(\mathrm{NP})$ & NA & bpa_10 & \\
\hline$\geq 4$ audit committee meetings/ year & NA & NA & $\mathrm{X}$ & NA & bpa_16 & \\
\hline
\end{tabular}




\begin{tabular}{|c|c|c|c|c|c|c|}
\hline ELEMENTS & BRAZIL & INDIA & KOREA & TURKEY & LABEL & \begin{tabular}{|l|} 
COMMON \\
INDEX-2
\end{tabular} \\
\hline \multicolumn{7}{|l|}{ Disclosure Subindex } \\
\hline RPTs are disclosed to shareholders & $\mathrm{X}(\mathrm{NP})$ & $\mathrm{X}$ & required & required & dis_1 & $\mathrm{X}$ \\
\hline Firm has regular meetings with analysts & $\mathrm{X}(\mathrm{NP})$ & $\mathrm{X}$ & $\mathrm{X}(\mathrm{NP})$ & NA & dis 2 & \\
\hline Firm discloses 5\% holders & common & $\mathrm{X}$ & required & avail & dis 3 & PUB \\
\hline Control group shareholder agreement disclosed & feas & $\mathrm{X}$ & NA & NA & dis_4 & \\
\hline Annual financials on firm website & NA & $\mathrm{X}$ & avail, NM & $\mathrm{X}$ & dis 5 & \\
\hline Quarterly financial statements are consolidated & $\mathrm{X}$ & feas & feas & required & dis_6 & \\
\hline Quarterly financials on firm website & NA & $\mathrm{X}$ & NA & $\mathrm{X}$ & dis_7 & \\
\hline Firm puts annual report on firm website & NA & $\mathrm{X}$ & NA & $\mathrm{X}$ & dis_8 & \\
\hline Directors' report on firm website & NM & $\mathrm{X}$ & NM & NM & dis_9 & \\
\hline Corp governance report on firm website & NM & $\mathrm{X}$ & NM & $\mathrm{X}$ & dis 10 & \\
\hline Firm discloses material events on firm website & NA & NA & NA & $\mathrm{X}$ & dis_11 & \\
\hline Firm discloses annual agenda of corporate events & $\mathrm{X}$ & NA & required & $\mathrm{X}$ & dis_12 & \\
\hline Firm charter available on firm website & NA & NA & NM & $\mathrm{X}$ & dis_14 & \\
\hline English language financial statements exist & $\mathrm{X}$ & NM & $\mathrm{X}(\mathrm{NP})$ & $\mathrm{X}$ & dis 15 & PUB \\
\hline Financials include statement of cash flows & $\mathrm{X}$ & required & required & required & dis_16 & PUB $_{\text {only }}$ \\
\hline Financial statements in IFRS or US GAAP & $\mathrm{X}$ & feas & rare & required & dis_17 & \\
\hline MD\&A discussion in financial statements & $\mathrm{X}$ & required & required & NA & dis_18 & \\
\hline Shareholder voting information on firm website & NA & NA & NA & $\mathrm{X}$ & dis_19 & \\
\hline Firm discloses list of insiders & NA & NA & NA & $\mathrm{X}$ & dis_20 & \\
\hline Firm discloses director shareholdings & NA & feas (NA) & required & $\mathrm{X}$ & dis 21 & \\
\hline Controlling shareholder disclosed & & & & $\mathrm{X}$ & dis 22 & \\
\hline Code of conduct/ethics contents disclosed & & & & $\mathrm{X}$ & dis_23 & \\
\hline Governance charter or guidelines disclosed & NA & avail $(\mathrm{NP})$ & NA & $\mathrm{X}$ & dis_24 & \\
\hline Annual meeting results disclosed & required & not avail & required & $\mathrm{X}$ & dis 25 & \\
\hline Board members' roles/employment disclosed & avail & NA & required & $\mathrm{X}$ & dis_26 & \\
\hline Board members' background disclosed & avail & NA & $\mathrm{X}$ & $\mathrm{X}$ & dis_27 & \\
\hline Board members date of joining board disclosed & feas & NA & required & $\mathrm{X}$ & dis_28 & \\
\hline Background of senior managers disclosed & avail & NA & No avail & $\mathrm{X}$ & dis_29 & \\
\hline Information re internal audit/control disclosed & NA & NA & required & $\mathrm{X}$ & dis_30 & \\
\hline Number of board meetings disclosed & avail $(\mathrm{NP})$ & feas (NP) & required & $\mathrm{X}$ & dis_31 & \\
\hline Board resolutions disclosed & NA & NA & required & $\mathrm{X}$ & dis 32 & \\
\hline Executive director compensation disclosed & NA & NA & required & $\mathrm{X}$ & dis_33 & \\
\hline Auditor does not provide non-audit services & $\mathrm{X}(\mathrm{NP})$ & $\mathrm{X}$ & feas & NA & dis_34 & \\
\hline Non-audit fees $<25 \%$ of total auditor fees & NA & $\mathrm{X}$ & feas & NA & dis 35 & \\
\hline Full board reviews auditor's recommendations & NA & $\mathrm{X}$ & NA & NA & dis_36 & \\
\hline Audit partner is rotated every 5 years & NM & $\mathrm{X}$ & feas & NA & dis_38 & \\
\hline \multicolumn{7}{|l|}{ Ownership Structure Subindex } \\
\hline Largest shareholder's fraction of common shares & $\mathrm{X}$ & avail & avail & $\mathrm{X}$ & own_1 & $\mathrm{X}$ \\
\hline Common shares/total shares & $\mathrm{X}$ & NM & NM & NM & own_2 & \\
\hline Ownership parity & $\mathrm{X}$ & $\begin{array}{c}\begin{array}{c}\text { disparity is } \\
\text { rare }\end{array} \\
\end{array}$ & $\mathrm{X}$ & $\mathrm{X}$ & own_3 & $\mathrm{X}$ \\
\hline Size of control group & $\mathrm{X}$ & NA & NA & NA & own 5 & \\
\hline Firm has an outside 5\% institutional investor & $\mathrm{X}$ & avail & feas & $\mathrm{X}$ & own_6 & \\
\hline Controllers do not have special nomination rights & NM & not allowed & not allowed & $\mathrm{X}$ & own_7 & \\
\hline Shares w. preferred voting rights do not exist & NM & not allowed & not allowed & $\mathrm{X}$ & own_8 & \\
\hline \multicolumn{7}{|l|}{ Shareholder Rights Subindex } \\
\hline All directors serve one year terms & $\mathrm{X}$ & avail (NP) & feas, rare & feas, rare & sr_1 & \\
\hline Outside directors serve one year terms & avail & $\mathrm{X}$ & feas & $\mathrm{X}$ & sr_2 & \\
\hline Firm allows voting by postal ballot & avail (NP) & $\mathrm{X}$ & $\mathrm{X}$ & Not allowed & sr_3 & \\
\hline Company has policy against insider trading & NA & $\mathrm{X}$ & NA & $\mathrm{X}$ & sr_4 & \\
\hline $\begin{array}{l}\text { Board includes at least one member elected by } \\
\text { minority shareholders }\end{array}$ & $\mathrm{X}(\mathrm{NP})$ & avail (NP) & $\mathrm{NA}$, rare & NA, rare & sr_5 & \\
\hline Cumulative voting for election of directors & avail $(\mathrm{NP})$ & not allowed & $\mathrm{X}$ & not allowed & sr_6 & $\mathrm{X}$ \\
\hline
\end{tabular}




\begin{tabular}{|c|c|c|c|c|c|c|}
\hline ELEMENTS & BRAZIL & INDIA & KOREA & TURKEY & LABEL & $\begin{array}{l}\text { COMMON } \\
\text { INDEX-2 }\end{array}$ \\
\hline $\begin{array}{l}\text { Director candidates disclosed to shareholders in } \\
\text { advance of shareholder meeting }\end{array}$ & avail (NP) & NA & $\mathrm{X}$ & NA & sr_8 & \\
\hline $\begin{array}{l}\text { No class of shares } \mathrm{w} \text {. special nomination rights } \\
\text { (except to give rights to } 2^{\text {nd }} \text { major shareholder) }\end{array}$ & not allowed & not allowed & not allowed & $\mathrm{X}$ & sr_9 & \\
\hline No class of shares w. multiple voting rights & not allowed & not allowed & not allowed & $\mathrm{X}$ & sr_10 & \\
\hline No founder shares or other special cash flow rights & not allowed & not allowed & not allowed & $\mathrm{X}$ & sr_11 & \\
\hline Firm has investor relations department or contact & required & avail & NA & $\mathrm{X}$ & sr_12 & \\
\hline Freezeout offer based on shares' economic value & $\mathrm{X}$ & required & required & required & $\mathrm{sr}=13$ & \\
\hline Takeout rights on sale of control $>$ legal minimum & $\mathrm{X}$ & NM & NM & NA & sr_14 & \\
\hline Disputes with shareholders subject to arbitration & $\mathrm{X}$ & $\mathrm{X}$ & NA & NA & sr_15 & \\
\hline Firm provides preemptive rights & $\mathrm{X}(\mathrm{NP})$ & required & required & common & sr_16 & \\
\hline Free float is at least $25 \%$ of total shares & $\mathrm{X}(\mathrm{NP})$ & feas & avail & avail & sr_17 & \\
\hline \multicolumn{7}{|l|}{ Related Party Transactions (RPT) Subindex } \\
\hline No loans to insiders & $\mathrm{X}$ & avail (NP) & NA & $\mathrm{X}$ & rpt_1 & \\
\hline No significant sales to/purchases from insiders & $\mathrm{X}$ & avail (NP) & avail & NA & rpt_2 & \\
\hline No real property rental from or to an insider & $\mathrm{X}$ & avail (NP) & feas & NA & rpt_3 & \\
\hline Negligible revenue from RPTs $(0-1 \%$ of sales $)$ & NA & avail (NP) & avail & avail & rpt_4 & \\
\hline No significant RPTs (RPTs/sales $<5 \%$ ) & NA & avail (NP) & avail & $\mathrm{X}$ & rpt_5 & \\
\hline $\begin{array}{l}\text { No RPTs needed board/audit committee approval } \\
\text { in last } 3 \text { years }\end{array}$ & NA & avail (NP) & feas & NA & rpt_6 & \\
\hline RPTs are on arms-length terms & NA & $\mathrm{X}$ & NM & NA & rpt_7 & \\
\hline RPTs require board approval & $\mathrm{X}(\mathrm{NP})$ & avail (NP) & $\mathrm{X}^{44}$ & required & rpt_ 8 & $\mathrm{X}$ \\
\hline RPTs approved by noninterested directors & $\mathrm{X}(\mathrm{NP})$ & avail (NP) & $\begin{array}{c}\text { required if }> \\
\text { threshold }\end{array}$ & required & rpt_9 & \\
\hline RPTs approved by noninterested shareholders & $\mathrm{X}(\mathrm{NP})$ & avail (NP) & NA & NA & rpt_10 & \\
\hline $\begin{array}{l}\text { RPTs with executives approved by board, audit } \\
\text { committee or shareholders }\end{array}$ & NA & $\mathrm{X}$ & required & NA & rpt_11 & \\
\hline $\begin{array}{l}\text { RPTs with executives approved by audit } \\
\text { committee or non-interested directors }\end{array}$ & NA & $\mathrm{X}$ & NA & NA & rpt_12 & \\
\hline RPTs with executives approved by shareholders & NA & $\mathrm{X}$ & feas, rare & NA & rpt_13 & \\
\hline $\begin{array}{l}\text { RPTs with controlling shareholder approved by } \\
\text { board, audit committee or shareholders }\end{array}$ & NA & $\mathrm{X}$ & $\begin{array}{c}\begin{array}{c}\text { required if }> \\
\text { threshold }\end{array} \\
\end{array}$ & NA & rpt_14 & \\
\hline $\begin{array}{l}\text { RPTs with controlling shareholder approved by } \\
\text { audit committee or non-interested directors }\end{array}$ & NA & $\mathrm{X}$ & NA & NA & rpt_15 & \\
\hline RPTs banned by company charter & $\mathrm{X}$ & NA & rare $(\mathrm{F})$ & NA & rpt_16 & \\
\hline
\end{tabular}

Cell entries: $X=$ element used; avail = element not used in country index, but data is available (we have it, or could obtain it without great effort). feas or $\mathrm{F}=$ element not used, data could be collected with substantial additional effort. $\mathrm{NA}=$ data not available. $\mathrm{NP}=$ data from private survey; not publicly available. $\mathrm{NM}=$ not meaningful (redundant, or involves institution unique to another country). Required = required by law. rare $=$ avail but rare (minimal within country variation); Common $=$ avail but nearly universal (minimal variation). Public index $=$ element is publicly avail in all countries. Entries in common index-2 column: $\mathrm{X}=$ element included in Common-2 Index (avail in all four countries; useful in two or more); PUB = publicly available in all four countries plus Russia and element is used in common-2 index; $\mathrm{PUB}_{\text {only }}$ is similar, but element is not part of Common-2 Index.

44 Included in Korea Shareholder Rights Subindex. 
Black et al.:

Table 3

Summary statistics and correlation coefficients.

\begin{tabular}{lccccc}
\hline Country & Brazil & India & Korea & Turkey & Russia \\
\hline \multicolumn{5}{c}{ Summary Statistics } \\
Period & $2004-2009$ & $2005-2012$ & $1998-2004$ & $2006-2011$ & $1999-2005$ \\
Mean & 62.13 & 59.17 & 33.90 & 42.49 & 0.00 \\
Median & 65.44 & 59.87 & 32.02 & 41.84 & 0.05 \\
Standard Deviation & 15.44 & 10.81 & 11.01 & 12.74 & 1.00 \\
Min. & 19.11 & 24.62 & 7.86 & 9.34 & -2.90 \\
Max. & 91.53 & 86.92 & 88.33 & 74.65 & 3.51 \\
First Year Mean & 53.34 & 57.28 & 24.64 & 41.56 & n.m. \\
Last Year Mean & 63.96 & 60.96 & 42.43 & 44.21 & n.m. \\
\hline \multicolumn{5}{c}{ Correlations } \\
CGI x Common-2 Index & $0.58^{*}$ & $0.50^{*}$ & $0.75^{*}$ & $0.53^{*}$ & n.m. \\
Non-common CGI x Common-2 & $0.52^{*}$ & $0.26^{*}$ & $0.62^{*}$ & $0.33^{*}$ & n.m. \\
Index & \multicolumn{7}{c}{} \\
\hline
\end{tabular}

Notes: Sample is pooled across years. Russian index is normalized. Other country indices are non-normalized (average of non-normalized sub-indices, each 0 100). CGI, Common-2, and non-common CGI indices are defined in the text. For correlations, $*=$ significant at $1 \%$ level. 
Table 4

Principal non-governance variables

\begin{tabular}{|c|c|c|c|c|}
\hline & Definitions & Winsorization & Used in & Ccmmon set \\
\hline Tobin's $q$ & (book value of debt + market value of common stock)/ book value of assets. & - & all & Yes \\
\hline $\ln ($ Tobin’s q) & Tobin's $q$ in logarithm & - & all & Yes \\
\hline $\ln$ (assets) & Book value of assets & - & all & Yes \\
\hline $\ln$ (listed years) & Years since public listing + one in logarithm. India: Use years since incorporation. & - & al $1-\mathrm{R}$ & Yes \\
\hline Leverage & Total liabilities over total assets. India: Use total debt. & $99 \%$ & all & yes \\
\hline Net Income/assets & Ratio of net income over assets & $1 \% / 99 \%$ & all & Yes \\
\hline EBIT/sales & Ratio of earnings before interest and tax (EBIT) to total sales & $1 \% / 99 \%$ & all - R & Yes \\
\hline 3 -yr sales growth & Geometric average sales growth during past three years (or available period if less). & $1 \% / 99 \%$ & all & Yes \\
\hline $\mathrm{PPE} / \mathrm{sales}$ & Ratio of property, plant, and equipment (PPE) to total sales & $99 \%$ & all - R & Yes \\
\hline Turnover & (shares traded in year $t) /($ shares outstanding), adjusted for share issuances and splits & $99 \%$ & all & Yes \\
\hline Inside ownership & Fractional ownership of common (and equivalent) shares by largest shareholder & - & all - R & Yes \\
\hline Foreign ownership & Fractional ownership by foreigners & - & all - R & - \\
\hline State ownership & Fractional ownership by the state & - & all - R & Yes \\
\hline Free Float & Fraction of shares floating on the stock exchange (excludes shares held by insiders) & - & all - I,R & Yes \\
\hline Capex/PPE & Ratio of capital expenditure to PPE & $99 \%$ & all - B,R & - \\
\hline R\&D/sales & Ratio of R\&D expenditure to total sales. & $99 \%$ & all - B,R & - \\
\hline Advertising/sales & Ratio of advertising expense to total sales. & $99 \%$ & all - B,R & - \\
\hline Exports/sales & Ratio of export revenue to total sales. & $99 \%$ & all - B,R & - \\
\hline Market share & Firm's share of sales by all public firms in same industry & - & all - B,R & - \\
\hline Business group & 1 if firm belongs to business group in year $t, 0$ otherwise. & - & all - R & yes \\
\hline MSCI & 1 if firm belongs to Morgan Stanley Capital International Index (MSCI). & - & all - B & - \\
\hline US cross listing & 1 if firm is cross-listed in US (any level) in year $t, 0$ otherwise & - & all - R & yes \\
\hline industry dummies & defined in each country; mapped to US 2-digit SIC codes when using common controls & & all - R & yes \\
\hline
\end{tabular}

Definitions of principal non-governance variables, winsorization level for regressions in which we winsorized control variables; and indication of which controls are available in each of Brazil (B), India (I), Korea (K), Russia (R), and Turkey (T). We drop firm-years with zero or negative sales. Last column indicated which control variables are available in Brazil, India, Korea, and Turkey; we use these variables in "common controls" regressions below. We replace missing values with zero for R\&D/sales, advertising/sales, and exports/sales. Income statement amounts are measured for each year $t$; balance sheet amounts at the end of each year $t$. 
Table 5

Regressions using country-specific indices and controls.

\begin{tabular}{|c|c|c|c|c|c|c|c|}
\hline \multicolumn{3}{|c|}{ dependent variable } & \multicolumn{5}{|c|}{$\ln ($ Tobin's q; outliers excluded) } \\
\hline Panel & & & Brazil & India & Korea & Turkey & Russia \\
\hline \multirow{4}{*}{1} & \multirow{4}{*}{$\begin{array}{l}\text { Cross-sectional OLS (first year in Brazil, } \\
\text { India, Turkey; } 2001 \text { in Korea, } 2003 \text { in } \\
\text { Russia) }\end{array}$} & Country CGI & $\begin{array}{c}0.150 * * * \\
(3.10)\end{array}$ & $\begin{array}{c}0.107 * * \\
(2.09)\end{array}$ & $\begin{array}{c}0.057 * * * \\
(3.73)\end{array}$ & $\begin{array}{c}0.121 * * * \\
(2.61)\end{array}$ & $\begin{array}{c}0.088 * * \\
(2.39)\end{array}$ \\
\hline & & No. of firms & 59 & 233 & 495 & 167 & 63 \\
\hline & & Adj. $\mathrm{R}^{2}$ & 0.55 & 0.32 & 0.54 & 0.41 & 0.84 \\
\hline & & Year & 2004 & 2006 & 2001 & 2006 & 2003 Q3 \\
\hline \multirow{4}{*}{2} & \multirow{4}{*}{ Pooled OLS } & Country CGI & $\begin{array}{c}0.106 * * * \\
(3.16)\end{array}$ & $\begin{array}{l}0.037 \\
(1.42) \\
\end{array}$ & $\begin{array}{c}\mathbf{0 . 0 5 2} * * * \\
(5.80)\end{array}$ & $\begin{array}{c}\mathbf{0 . 0 7 3} * * * \\
(2.89)\end{array}$ & $\begin{array}{c}\mathbf{0 . 1 4 8} * * * \\
(6.19)\end{array}$ \\
\hline & & No. of obs. (firms) & $236(159)$ & $636(399)$ & $3,285(668)$ & $974(193)$ & $964(99)$ \\
\hline & & Adj. $R^{2}$ & 0.35 & 0.30 & 0.53 & 0.48 & 0.66 \\
\hline & & Period & 2004-09 & 2006-12 & $1998-2004$ & $2006-11$ & 1999-2005 \\
\hline \multirow{6}{*}{3} & \multirow{6}{*}{ Firm Random Effects } & Country CGI & $\begin{array}{c}0.114 * * * \\
(3.03)\end{array}$ & $\begin{array}{c}0.064 * * \\
(2.57)\end{array}$ & $\begin{array}{c}0.048 * * * \\
(6.26)\end{array}$ & $\begin{array}{c}0.065 * * * \\
(2.73)\end{array}$ & $\begin{array}{c}0.094 * * * \\
(6.22)\end{array}$ \\
\hline & & No. of obs. (firms) & $236(159)$ & $636(399)$ & $3,285(668)$ & $974(193)$ & $964(99)$ \\
\hline & & Breusch-Pagan test & 0.0000 & 0.0000 & 0.0000 & 0.0000 & 0.0000 \\
\hline & & Hausman test & 0.0001 & n.a. & 0.0000 & 0.0000 & n.a. \\
\hline & & Median $\lambda$ & 0.33 & 0.30 & 0.63 & 0.66 & 0.71 \\
\hline & & Overall $\mathrm{R}^{2}$ & 0.40 & 0.33 & 0.53 & 0.48 & 0.63 \\
\hline \multirow{3}{*}{4} & \multirow{3}{*}{ Firm Fixed Effects } & Country CGI & $\begin{array}{l}0.088 \\
(1.15)\end{array}$ & $\begin{array}{c}0.075 * * \\
(2.27)\end{array}$ & $\begin{array}{c}0.045 * * * \\
(5.33)\end{array}$ & $\begin{array}{c}0.050^{*} \\
(1.88)\end{array}$ & $\begin{array}{c}0.067 * * * \\
(2.75)\end{array}$ \\
\hline & & No. of obs. (firms) & $146(72)$ & $423(186)$ & $3,252(636)$ & $971(190)$ & $964(99)$ \\
\hline & & Within $\mathrm{R}^{2}$ & 0.50 & 0.34 & 0.38 & 0.52 & 0.45 \\
\hline
\end{tabular}

Notes: Table shows coefficients for indicated regressions of $\ln$ (Tobin's $q$ ) on country CGI and control variables. Country CGI is renormalized sum of normalized subindices ( $m e a n=0 ; \sigma=1$ ). Control variables are listed in Table 4. Time-invariant dummy variables (industry, business group, US cross listing, MSCI) drop out with firm fixed effects. Observations are excluded as outliers if a studentized residual from regressing $\ln$ (Tobin's $q$ ) on CGI (year-by-year for panel data) $> \pm 1.96$. Pooled regressions in Panels 2-4 use year dummies. OLS and random effects regressions include industry dummies. Fixed effects sample excludes firms observed only once. $t$-statistics (heteroskedasticity-consistent for cross-sectional OLS; firm clusters otherwise (firm-index clusters in Russia)) are in parentheses. * **, and *** respectively indicate significance levels at $10 \%, 5 \%$, and $1 \%$ levels. Significant results (at $5 \%$ level or better) are in boldface. Values for Breusch-Pagan and Hausman tests are $p$-values. 
Table 6. Pure cross-sectional OLS

Cross-sectional OLS regressions using country-specific indices and controls, for selected years.

\begin{tabular}{|c|c|c|c|c|c|c|}
\hline \multirow{2}{*}{\multicolumn{2}{|c|}{ dependent variable }} & \multicolumn{5}{|c|}{$\ln ($ Tobin's q; outliers excluded) } \\
\hline & & Brazil & India & Korea & Turkey & Russia \\
\hline \multirow[b]{2}{*}{ Year 1} & Country CGI & $\begin{array}{c}0.150 * * * \\
(3.10)\end{array}$ & $\begin{array}{c}0.107 * * \\
(2.09) \\
\end{array}$ & $\begin{array}{c}-0.0103 \\
(-0.60) \\
\end{array}$ & $\begin{array}{c}0.121 * * * \\
(2.56)\end{array}$ & $\begin{array}{l}0.029 \\
(0.34) \\
\end{array}$ \\
\hline & $\begin{array}{l}\text { No. of firms } \\
\text { Adj. } R^{2} \\
\text { Year }\end{array}$ & $\begin{array}{c}59 \\
0.55 \\
\mathbf{2 0 0 4}\end{array}$ & $\begin{array}{c}233 \\
0.32 \\
\mathbf{2 0 0 6}\end{array}$ & $\begin{array}{c}429 \\
0.47 \\
1998\end{array}$ & $\begin{array}{c}167 \\
0.41 \\
\mathbf{2 0 0 6}\end{array}$ & $\begin{array}{c}46 \\
0.573 \\
\text { 2H2000 }\end{array}$ \\
\hline \multirow[b]{2}{*}{ Year 2} & Country CGI & $\begin{array}{l}0.073 \\
(1.22)\end{array}$ & $\begin{array}{c}-0.000 \\
(-0.010)\end{array}$ & $\begin{array}{c}0.057 * * * \\
(3.73)\end{array}$ & $\begin{array}{l}-0.043 \\
(-0.87)\end{array}$ & $\begin{array}{c}0.119 * * * \\
(3.09)\end{array}$ \\
\hline & $\begin{array}{l}\text { No. of firms } \\
\text { Adj. } \mathrm{R}^{2} \\
\text { Year }\end{array}$ & $\begin{array}{c}76 \\
0.41 \\
\mathbf{2 0 0 6}\end{array}$ & $\begin{array}{c}261 \\
0.43 \\
\mathbf{2 0 0 7} \\
\end{array}$ & $\begin{array}{c}495 \\
0.54 \\
\mathbf{2 0 0 1} \\
\end{array}$ & $\begin{array}{l}165 \\
0.33 \\
\mathbf{2 0 0 9}\end{array}$ & $\begin{array}{c}81 \\
0.785 \\
\mathbf{2 H 2 0 0 3}\end{array}$ \\
\hline \multirow[b]{2}{*}{ Year 3} & Country CGI & $\begin{array}{l}0.062 \\
(1.43) \\
\end{array}$ & $\begin{array}{c}-0.058 \\
(-1.308) \\
\end{array}$ & $\begin{array}{c}0.0193 \\
(0.97) \\
\end{array}$ & $\begin{array}{l}0.063 \\
(1.15) \\
\end{array}$ & $\begin{array}{c}0.184 * * * \\
(3.40)\end{array}$ \\
\hline & $\begin{array}{l}\text { No. of firms } \\
\text { Adj. } R^{2} \\
\text { Year }\end{array}$ & $\begin{array}{l}101 \\
0.13 \\
\mathbf{2 0 0 9}\end{array}$ & $\begin{array}{c}142 \\
0.37 \\
\mathbf{2 0 1 2}\end{array}$ & $\begin{array}{l}473 \\
0.53 \\
\mathbf{2 0 0 4}\end{array}$ & $\begin{array}{l}158 \\
0.28 \\
\mathbf{2 0 1 1}\end{array}$ & $\begin{array}{c}73 \\
0.56 \\
\mathbf{2 H 2 0 0 5}\end{array}$ \\
\hline
\end{tabular}

Notes: Table shows coefficients for indicated regressions of $\ln$ (Tobin's $q$ ) on country CGI and control variables for indicated years: We show results for all available years for Brazil and India; and one early, one middle and the last sample year for Korea, Turkey, and Russia. Country CGI is renormalized sum of normalized subindices (mean $=0 ; \sigma=1)$. Control variables are listed in Table 4. Observations are identified as outliers if a studentized residual from regressing $\ln$ (Tobin's $q$ ) on CGI $> \pm 1.96 . t$-statistics (heteroskedasticity-consistent) are in parentheses. ${ }^{*}, * *$, and $* * *$ respectively indicate significance levels at $10 \%, 5 \%$, and $1 \%$ levels. Significant results (at $5 \%$ level or better) are in boldface. 
Table 7

Alternative specifications for firm fixed effects (FE) and random effects (RE) regressions

\begin{tabular}{|c|c|c|c|c|c|c|c|c|c|c|}
\hline \multirow[b]{2}{*}{ Pane } & & \multirow[b]{2}{*}{ specification } & \multicolumn{2}{|c|}{ Brazil } & \multicolumn{2}{|c|}{ India } & \multicolumn{2}{|c|}{ Korea } & \multicolumn{2}{|c|}{ Turkey } \\
\hline & & & $\mathbf{R E}$ & FE & RE & FE & $\mathbf{R E}$ & FE & RE & FE \\
\hline \multirow{2}{*}{1} & \multirow{2}{*}{$\begin{array}{l}\text { Base specification } \\
\text { (fromTable 5) }\end{array}$} & CGI & $\begin{array}{c}0.114 * * * \\
(3.03) \\
\end{array}$ & $\begin{array}{l}0.088 \\
(1.15) \\
\end{array}$ & $\begin{array}{c}0.064 * * \\
(2.57) \\
\end{array}$ & $\begin{array}{c}0.075 * * \\
(2.27) \\
\end{array}$ & $\begin{array}{c}\mathbf{0 . 0 4 8 * * *} \\
(\mathbf{6 . 2 6})\end{array}$ & $\begin{array}{c}0.045 * * * \\
(5.33)\end{array}$ & $\begin{array}{c}0.065 * * * \\
(2.73) \\
\end{array}$ & $\begin{array}{l}0.050 * \\
(1.88)\end{array}$ \\
\hline & & $\begin{array}{c}\text { Obs. (firms) } \\
\mathrm{R}^{2}\end{array}$ & $\begin{array}{c}236(159) \\
0.40\end{array}$ & $\begin{array}{c}146(72) \\
0.50\end{array}$ & $\begin{array}{c}636(399) \\
0.33\end{array}$ & $\begin{array}{c}423(186) \\
0.34\end{array}$ & $\begin{array}{c}3,285(669) \\
0.53\end{array}$ & $\begin{array}{c}3,252(636) \\
0.38\end{array}$ & $\begin{array}{c}974(193) \\
0.48\end{array}$ & $\begin{array}{c}971(190) \\
0.52\end{array}$ \\
\hline \multirow[t]{2}{*}{2} & \multirow[t]{2}{*}{ Common controls } & CGI & $\begin{array}{c}0.114 * * * \\
(3.03)\end{array}$ & $\begin{array}{l}0.088 \\
(1.15) \\
\end{array}$ & $\begin{array}{c}0.068 * * * \\
(2.68) \\
\end{array}$ & $\begin{array}{c}0.083 * * * \\
(2.66) \\
\end{array}$ & $\begin{array}{c}0.060 * * * \\
(7.40) \\
\end{array}$ & $\begin{array}{c}0.055 * * * \\
(6.26) \\
\end{array}$ & $\begin{array}{c}0.064 * * * \\
(2.49) \\
\end{array}$ & $\begin{array}{l}0.048^{*} \\
(1.72) \\
\end{array}$ \\
\hline & & $\mathrm{R}^{2}$ & 0.40 & 0.50 & 0.35 & 0.30 & 0.45 & 0.34 & 0.48 & 0.50 \\
\hline \multirow[t]{2}{*}{3} & \multirow[t]{2}{*}{ Winsorize controls } & CGI & $\begin{array}{c}0.114 * * * \\
(3.03)\end{array}$ & $\begin{array}{l}0.088 \\
(1.15)\end{array}$ & $\begin{array}{c}0.065 * * * \\
(2.67)\end{array}$ & $\begin{array}{c}0.080 * * \\
(2.42)\end{array}$ & $\begin{array}{c}0.047 * * * \\
(6.35)\end{array}$ & $\begin{array}{c}0.044 * * * \\
(5.30)\end{array}$ & $\begin{array}{c}0.063 * * * \\
(2.62)\end{array}$ & $\begin{array}{l}0.048^{*} \\
(1.82)\end{array}$ \\
\hline & & $\mathrm{R}^{2}$ & 0.40 & 0.50 & 0.35 & 0.37 & 0.54 & 0.40 & 0.48 & 0.52 \\
\hline \multirow[t]{2}{*}{4} & \multirow[t]{2}{*}{ Limited control variables } & CGI & $\begin{array}{c}0.112 * * * \\
(2.97)\end{array}$ & $\begin{array}{l}0.096 \\
(1.10)\end{array}$ & $\begin{array}{c}0.080 * * * \\
(3.15)\end{array}$ & $\begin{array}{c}0.086 * * \\
(2.76)\end{array}$ & $\begin{array}{c}0.057 * * * \\
(7.08)\end{array}$ & $\begin{array}{c}0.049 * * * \\
(5.43)\end{array}$ & $\begin{array}{l}0.065 * * \\
(2.51)\end{array}$ & $\begin{array}{c}0.068 * * \\
(2.48)\end{array}$ \\
\hline & & $\mathrm{R}^{2}$ & 0.28 & 0.37 & 0.25 & 0.26 & 0.24 & 0.19 & 0.38 & 0.45 \\
\hline \multirow[t]{2}{*}{5} & \multirow{2}{*}{$\begin{array}{l}\text { Very limited controls, similar } \\
\text { to Durnev and Kim (2005) }\end{array}$} & CGI & $\begin{array}{c}0.127 * * * \\
(4.17) \\
\end{array}$ & $\begin{array}{c}0.162 * * * \\
(3.79)\end{array}$ & $\begin{array}{c}0.077 * * * \\
(3.12)\end{array}$ & $\begin{array}{c}0.080 * * * \\
(2.55)\end{array}$ & $\begin{array}{c}0.057 * * * \\
(7.14)\end{array}$ & $\begin{array}{c}0.047 * * * \\
(5.51)\end{array}$ & $\begin{array}{c}\mathbf{0 . 0 6 9} * * * \\
(2.71)\end{array}$ & $\begin{array}{c}\mathbf{0 . 0 7 7} * * * \\
(2.70)\end{array}$ \\
\hline & & $\mathrm{R}^{2}$ & 0.21 & 0.31 & 0.17 & 0.24 & 0.22 & 0.19 & 0.38 & 0.44 \\
\hline \multirow[t]{2}{*}{6} & \multirow[t]{2}{*}{ Winsorize $\ln ($ Tobin's $q$ ) } & CGI & $\begin{array}{c}0.0807 * \\
(1.85) \\
\end{array}$ & $\begin{array}{l}0.057 \\
(0.66) \\
\end{array}$ & $\begin{array}{l}0.048 \\
(1.26) \\
\end{array}$ & $\begin{array}{l}0.015 \\
(0.31) \\
\end{array}$ & $\begin{array}{c}0.043 * * * \\
(5.01)\end{array}$ & $\begin{array}{c}0.035 * * * \\
(3.57) \\
\end{array}$ & $\begin{array}{c}0.080 * * * \\
(2.78)\end{array}$ & $\begin{array}{c}.073 * * \\
(2.30)\end{array}$ \\
\hline & & $\mathrm{R}^{2}$ & 0.45 & 0.49 & 0.24 & 0.30 & 0.51 & 0.36 & 0.52 & 0.47 \\
\hline \multirow[t]{2}{*}{7} & \multirow{2}{*}{$\begin{array}{l}\ln (q) \text {, neither winsorize nor } \\
\text { exclude outliers }\end{array}$} & CGI & $\begin{array}{c}0.0807^{*} \\
(1.84)\end{array}$ & $\begin{array}{l}0.052 \\
(0.60)\end{array}$ & $\begin{array}{l}0.041 \\
(0.90)\end{array}$ & $\begin{array}{l}0.003 \\
(0.06)\end{array}$ & $\begin{array}{c}0.041 * * * \\
(4.41)\end{array}$ & $\begin{array}{c}0.032 * * * \\
(2.98)\end{array}$ & $\begin{array}{c}0.079 * * * \\
(2.73)\end{array}$ & $\begin{array}{c}0.068 * * \\
(2.09)\end{array}$ \\
\hline & & & 0.45 & 0.49 & 0.23 & 0.29 & 0.51 & 0.35 & 0.57 & 0.49 \\
\hline \multirow[t]{2}{*}{8} & \multirow{2}{*}{$\begin{array}{l}\text { raw Tobin's } q \text { (exclude } \\
\text { outliers) }\end{array}$} & CGI & $\begin{array}{c}0.0929 \\
(1.28)\end{array}$ & $\begin{array}{l}0.080 \\
(0.47)\end{array}$ & $\begin{array}{l}0.552 \\
(1.33)\end{array}$ & $\begin{array}{l}0.199 \\
(0.36)\end{array}$ & $\begin{array}{c}0.034 * * * \\
(4.92)\end{array}$ & $\begin{array}{c}0.030 * * * \\
(3.84)\end{array}$ & $\begin{array}{l}0.208 \\
(1.58)\end{array}$ & $\begin{array}{l}0.263 \\
(1.61)\end{array}$ \\
\hline & & $\mathrm{R}^{2}$ & 0.36 & 0.51 & 0.14 & 0.26 & 0.52 & 0.35 & 0.25 & 0.13 \\
\hline \multirow[t]{2}{*}{9} & \multirow{2}{*}{$\begin{array}{l}\text { dep. variable } \\
\ln (\text { market/book); exclude } \\
\text { outliers }\end{array}$} & CGI & $\begin{array}{c}0.197 * * * \\
(3.08)\end{array}$ & $\begin{array}{l}0.159 \\
(1.24)\end{array}$ & $\begin{array}{c}0.096 * * * \\
(2.60)\end{array}$ & $\begin{array}{c}0.116 * * * \\
(2.72)\end{array}$ & $\begin{array}{c}0.101 * * * \\
(4.77)\end{array}$ & $\begin{array}{c}0.088 * * * \\
(3.69)\end{array}$ & $\begin{array}{c}0.056 * * \\
(1.99)\end{array}$ & $\begin{array}{l}0.036 \\
(1.23)\end{array}$ \\
\hline & & $\mathrm{R}^{2}$ & 0.45 & 0.37 & 0.30 & 0.37 & 0.45 & 0.32 & 0.53 & 0.59 \\
\hline \multirow{2}{*}{\multicolumn{2}{|c|}{ Common-2 Index }} & CGI & $\begin{array}{l}0.0315 \\
(1.16) \\
\end{array}$ & $\begin{array}{c}0.0208 \\
(0.54) \\
\end{array}$ & $\begin{array}{r}0.019 \\
(0.63) \\
\end{array}$ & $\begin{array}{l}-0.005 \\
(-0.12) \\
\end{array}$ & $\begin{array}{c}0.0136 * * \\
(2.23) \\
\end{array}$ & $\begin{array}{l}0.0093 \\
(1.39) \\
\end{array}$ & $\begin{array}{l}0.003 \\
(0.14) \\
\end{array}$ & $\begin{array}{l}0.009 \\
(0.30) \\
\end{array}$ \\
\hline & & $\mathrm{R}^{2}$ & 0.38 & 0.48 & 0.37 & 0.33 & 0.44 & 0.34 & 0.46 & 0.51 \\
\hline
\end{tabular}

Notes: Table shows coefficients for indicated regressions of $\ln$ (Tobin's $q$ ) on country CGI and control variables. Sample and country indices are same as in

Table 5; dependent variable, means of addressing outliers, and control variables (coefficients suppressed) are same as Table 5 except as indicated. Table 4 discusses how we winsorize controls. Limited control variables in Panel 4 are $\ln ($ assets; $\ln ($ years listed +1 ); 3 -year sales growth, PPE/sales, R\&D/sales, exports/sales; 2-digit US SIC industry dummies, and cross-listing dummy. $t$-statistics (using firm clusters) in parentheses. $\mathrm{R}^{2}$ is overall for random effects; within for fixed effects. *, ${ }^{* *}$, and ${ }^{* * *}$ respectively indicate significance levels at $10 \%, 5 \%$, and $1 \%$ levels. Significant results (at $5 \%$ level or better) in boldface. 
Table 8

Multicountry Regressions with Pooled CGI, Common-2 Index, and Non-common CGI.

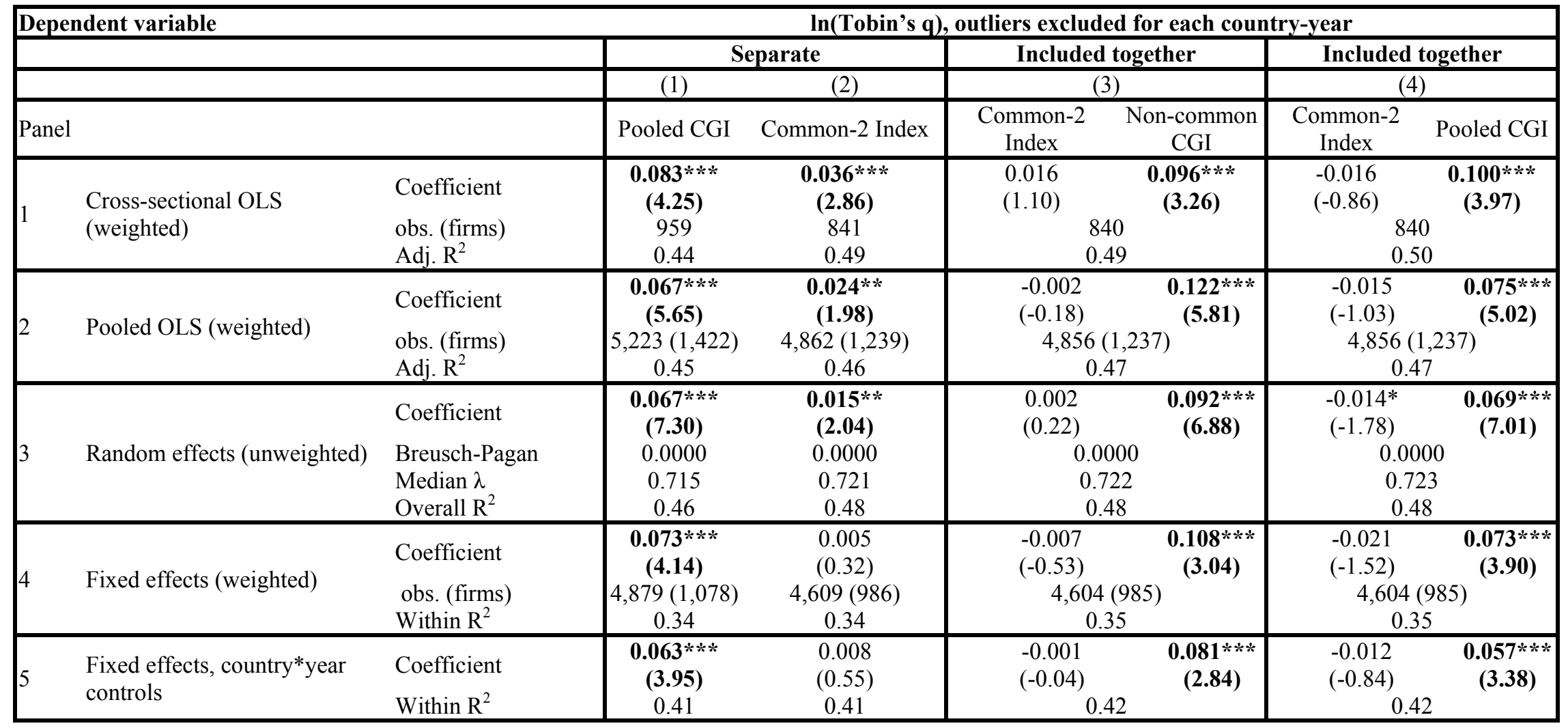

Notes: Coefficients on governance indices from indicated OLS, random effects (RE), and fixed effects (FE) regressions. Sample is pooled across countries and (except for Panel 1) sample years. Pooled CGI index uses country CGI values (defined in text) for Brazil, India, Korea, and Turkey. Common-2 index is defined in text. Country-level Non-common CGI indices are constructed in same manner as country-CGI, using elements that are not part of Common-2 Index, then combined into a multicountry Non-common CGI Index. All regressions use winsorized common control variables (shown in Table 4); coefficients are suppressed. In Panel 5, we interact each control variable with country dummies. OLS and RE regressions include industry dummies. Panel 1 includes country dummies; other panels include year*country dummies. Pooled OLS and FE regressions use country weights $=(1 /$ no. of firms $)$; weights are not available with RE. Observations are excluded as outliers if a studentized residual from regressing $\ln$ (Tobin's $q$ ) on CGI (within country, year-by-year, for panel data) $> \pm 1.96$. FE sample excludes firms observed only once. $t$-statistics (heteroskedasticity-consistent for cross-sectional OLS; firm clusters otherwise) are in parentheses. *, **, and *** respectively indicate significance levels at $10 \%, 5 \%$, and $1 \%$ levels. Significant results (at $5 \%$ level or better) are in boldface. Values for BreuschPagan test are $p$-values. 